\title{
Relationship between the distribution of vegetation and the environment in the coastal embryo dunes of Jalisco, México
}

\author{
Héctor Gerardo Frías-Ureña ${ }^{1}$, José Ariel Ruiz-Corral ${ }^{\text {Corresp., }}{ }^{1}$, Miguel Ángel Macías-Rodríguez ${ }^{1}$, Noé Durán ${ }^{2}$, Diego \\ Gonzalez $^{2}$, Fabio De Albuquerque ${ }^{3}$, José Pablo Torres Morán ${ }^{2}$ \\ ${ }^{1}$ Departamento de Ciencias Ambientales, Universidad de Guadalajara, Zapopan, Jalisco, México \\ 2 Departamento de Producción Sustentable, Universidad de Guadalajara, Zapopan, Jalisco, México \\ 3 School of Life Sciences Interdisciplinary Graduate Faculty, Arizona State University, Phoenix, Arizona, United States \\ Corresponding Author: José Ariel Ruiz-Corral \\ Email address: ariel.ruiz@academicos.udg.mx
}

Background. The poorly developed soils of the embryo dunes imply little capacity for plant support, however, the adaptation mechanisms of plants respond sensitively to environmental variations, even when these variations are small, which results in a set of specialized habitats and flora that are rarely shared with other terrestrial ecosystems. The coastal dunes of the Mexican Pacific remain vaguely studied, this is why this research explored the relationship between environmental properties and the presence of plant species in the embryo dunes of the coast of Jalisco, Mexico. Methods. Twenty-nine sites were sampled, 1 or 2 sites per embryo dune, with a random stratified design. Geomorphological and vegetation data were collected at site. Laboratory determinations included soil color, particle size, organic matter, pH, electrical conductivity, magnetite content, and moisture retention. Statistical analysis included correlation analysis to identify relationships between environmental variables; principal component analysis (PCA) and cluster analysis to group dune sites by environmental properties; canonical correspondence analysis (CCA) to determine a possible significant relationship between the presence of plant species and environmental variables; cluster analysis to group dune sites by presence/absence of plant species and correlate both clusters to validate the relationship between them, the salient aspects of this relationship were described and the spatial distribution of the groups was mapped. Results. Eleven plant species were identified, six of them exclusive to the embryo dunes and the rest ubiquitous. The incipient development of these soils is reflected in a low content of organic matter, silt, clay, and moisture retention, with scattered data on granulometry, electrical conductivity, organic matter, and magnetite. Some significant correlations were found between some environmental properties, and the CCA showed a significant relationship between the presence of plant species and environmental variables ( $p$-value of the Monte Carlo test $=$ 
0.026). The cluster analysis of dune sites according to environmental variables and the cluster analysis by presence/absence of plant species produces the formation of five groups of sites with significant environmental differences and five groups of sites with significant floristic differences. A significant connection ( $r=0.471, p=0.01)$ between the two clustering schemes also evidences the meaningful relationship between the presence of plant species and the environmental characteristics of the embryo dunes of Jalisco, Mexico. Differences in habitat preferences were observed among plant species exclusive to the embryo dunes; thus, Abronia maritima, Uniola pittieri, and Pectis arenaria showed a preference for embryo dunes with poor edaphic conditions, in contrast to Okenia hypogaea, Canavalia rosea, and Scaevola plumieri, which were mostly found in embryo dunes with higher fertility. 
1 Relationship between the distribution of vegetation

2 and the environment in the coastal embryo dunes of

3 Jalisco, México

4

5

6

7

8

Héctor Gerardo Frías-Ureña ${ }^{1}$, José Ariel Ruiz-Corral ${ }^{1}$, Miguel Ángel Macías-Rodríguez ${ }^{1}$, Noé Durán-Puga ${ }^{2}$, Diego González ${ }^{2}$, Fabio de Albuquerque ${ }^{3}$, José Pablo Torres-Morán ${ }^{2}$

${ }^{1}$ Departamento de Ciencias Ambientales, Universidad de Guadalajara, Zapopan, Jalisco, México

${ }^{2}$ Departamento de Producción Sustentable, Universidad de Guadalajara, Zapopan, Jalisco, México

${ }^{3}$ School of Life Sciences Interdisciplinary Graduate Faculty, Arizona State University, Phoenix, Arizona, USA

Corresponding Author:

José Ariel Ruiz-Corral

Camino Ing. Ramón Padilla Sánchez No. 2100, Zapopan, Jalisco, CP 45110, México

Email address: ariel.ruiz@academicos.udg.mx

\section{Abstract}

Background. The poorly developed soils of the embryo dunes imply little capacity for plant support, however, the adaptation mechanisms of plants respond sensitively to environmental variations, even when these variations are small, which results in a set of specialized habitats and flora that are rarely shared with other terrestrial ecosystems. The coastal dunes of the Mexican Pacific remain vaguely studied, this is why this research explored the relationship between environmental properties and the presence of plant species in the embryo dunes of the coast of Jalisco, Mexico.

Methods. Twenty-nine sites were sampled, 1 or 2 sites per embryo dune, with a random stratified design. Geomorphological and vegetation data were collected at site. Laboratory determinations included soil color, particle size, organic matter, $\mathrm{pH}$, electrical conductivity, magnetite content, and moisture retention. Statistical analysis included correlation analysis to identify relationships between environmental variables; principal component analysis (PCA) and cluster analysis to group dune sites by environmental properties; canonical correspondence analysis (CCA) to determine a possible significant relationship between the presence of plant species and environmental variables; cluster analysis to group dune sites by presence/absence of plant species and correlate both clusters to validate the relationship between them, the salient aspects of this relationship were described and the spatial distribution of the groups was mapped. 
39 Results. Eleven plant species were identified, six of them exclusive to the embryo dunes and the

40

41

42

43

44

45

46

47

48

49

50

51

52

53

54

55

56

57

58

59

60

61

62

63

64

65

66

67

68

69

70

71

72

73

74

75

76

77

78

rest ubiquitous. The incipient development of these soils is reflected in a low content of organic matter, silt, clay, and moisture retention, with scattered data on granulometry, electrical conductivity, organic matter, and magnetite. Some significant correlations were found between some environmental properties, and the CCA showed a significant relationship between the presence of plant species and environmental variables ( $p$-value of the Monte Carlo test $=0.026$ ). The cluster analysis of dune sites according to environmental variables and the cluster analysis by presence/absence of plant species produces the formation of five groups of sites with significant environmental differences and five groups of sites with significant floristic differences. A significant connection $(r=0.471, \mathrm{p}=0.01)$ between the two clustering schemes also evidences the meaningful relationship between the presence of plant species and the environmental characteristics of the embryo dunes of Jalisco, Mexico. Differences in habitat preferences were observed among plant species exclusive to the embryo dunes; thus, Abronia maritima, Uniola pittieri, and Pectis arenaria showed a preference for embryo dunes with poor edaphic conditions, in contrast to Okenia hypogaea, Canavalia rosea, and Scaevola plumieri, which were mostly found in embryo dunes with higher fertility.

\section{Introduction}

Coastal dune ecosystems present a unique set of habitats with high environmental variability and specialized flora, which is rarely shared with other terrestrial ecosystems (Acosta, Carranza \& Izzi, 2009; Ciccarelli, 2014; Angiolini, Bonari \& Landi, 2018). These ecosystems present a natural stress gradient, perpendicular to the coastline, leading to compressed zoning of plant communities (Acosta et al., 2003; Forey et al., 2008; Carboni, Santoro \& Acosta, 2011).

Influence of geomorphological aspects includes the elevation effect of dunes over sedimentation rate, soil sand content, and soil $\mathrm{pH}$, which increase with higher elevations, whereas soil clay, fine silt, soil moisture, organic matter, total $\mathrm{N}$, total $\mathrm{K}$ content, growth, and biodiversity of sand dune plants generally decrease with lower elevations (Pan, Zhang \& Li, 2016).

Some characteristic properties that have been reported for primary dunes systems include the presence of a $\mathrm{pH}$ gradient, which decreases with distance from the shoreline; poor fertility conditions, and spatial variation in electrical conductivity (Kim \& Yu, 2009; Willis et al., 2016). The absence of a relationship between soil chemical characteristics and plant community structure has also been reported (Willis et al., 2016).

Soil properties in coastal dunes determine important aspects of the vegetation establishment, functionality, and diversity. Soil organic matter determines plant biomass parameters, microorganisms, soil animals, and diversity of microarthropods; while $\mathrm{pH}$ establishes fundamental differences in the availability of phosphorus, thereby promoting vegetation

PeerJ reviewing PDF | (2021:07:63863:1:1:NEW 25 Jan 2022) 
82

83

84

85

86

87

88

89

90

91

92

93

94

95

96

97

98

99

100

101

102

103

104

105

106

107

108

109

110

111

112

113

114

115

116

117

118

strategies for the absorption of this element (Kooijman et al., 2020). Soil total organic carbon, total Nitrogen, Sodium, and total Phosphorus majorly determine bacterial communities structure (Gao et al., 2019).

Zuo et al. (2008), suggest that in a mobile dune, the distribution of plants is determined by a combination of edaphic properties and topographic aspects. In addition, Zuo et al. (2009) point out that the magnitude and degree of spatial heterogeneity in soil properties can influence the distribution pattern of plants and the plant succession of mobile dunes. These authors conclude that organic carbon, total nitrogen, electrical conductivity, $\mathrm{pH}$, the slope of the land, very fine sand content, and water content in soil are the main factors that influence the presence and distribution of dune plants, and therefore diversity of vegetation. The distribution of dune plant species obeys the concordance between the spatial distribution of soil properties in dunes and environmental requirements from plant species. Diverse studies have shown this phenomenon, such as the research from Willis et al. (2016) who reported that Ipomoea pes-caprae and Spinifex littoreus were restricted to the foredunes, the leguminous forb Alysicarpus vaginalis and Perotis indica to the furthest sites from the strand, and Ischaemum indicum, a C4 perennial grass species, which was found to be ubiquitous to all sampled sites.

Dunes involve poorly developed soils, where vegetation plays a key role in the soil evolution process and the formation of microenvironments (Moreno-Casasola, 1982). The degree of stabilization of dune soils strongly depends on vegetation cover (Provoost, Jones \& Edmonson, 2011). This is why many coastal foredune systems gain stabilization of the foredune morphology when vegetation cover is increased, moreover, since the fordune surface gets more stable, blowout events decrease (Martínez, Hesp \& Gallego-Fernández, 2013; Schwarz, Brinkkemper \& Ruessink, 2019). Vegetation contributes to the stabilization of dune soils by preventing erosion (Gao et al., 2019), promoting rainwater infiltration (Regüés et al., 2017), providing organic matter (Li et al., 2017), and contributing to a gradual improvement of soil structure (TorresGuerrero et al., 2013).

The degree of stabilization of coastal dune soils gives rise to a classification in terms of mobile, semi-mobile, and stabilized zones; in mobile zones dune soils of the Gulf of Mexico, the first species to establish are tufted grasses and subshrub plants, which stop erosion and allow the accumulation of sand; they are considered the main initial fixers of the substrate (Martínez \& Valverde, 1992). However, recently Biel, Hacker \& Ruggiero (2019) concluded that duneforming species also include annual and perennial forbs with prostrate growth patterns and species that primarily propagate by seed, rhizomes, and stolons; furthermore, they found that sand accretion in dunes is strongly influenced by patterns of vegetation growth.

Coastal dunes are key ecosystems, with particular geomorphological and sedimentary characteristics, which provide extremely important environmental services, such as coping with 
119 rising sea levels to prevent impacts inland; it is estimated that in México there is approximately 120800,000 ha of coastal dunes, distributed in around 80\% of the Mexican coastline (Jiménez-

121 Orocio, Espejel \& Martínez, 2015). Coastal dune vegetation and soils have been studied more in 122 the Gulf of México than in the Pacific Ocean coastline; therefore, most of the soils and 123 vegetation of this region remain unstudied, which limits the full understanding of its formation 124 and evolution process.

125

The objective of this research was to identify the edaphic and geomorphological properties that 127 majorly determine the presence of plant species in the coastal embryo dunes of Jalisco, México. Embryo dunes are often ephemeral but can develop to become established coastal foredunes (Montreuil et al., 2013b). Embryo dunes presence and extension depend on beach width, storm

130

131

132

133

134

135

136

137

138

139

140

141

142

143

144

145

146

147

148

149

150

151

152

153

154

155

156

157

158 intensity and frequency, growing season precipitation, and sand nourishment (van Puijenbroek et al., 2017). Severe storms surge events cause areas of erosion between dunes, aligned with the dominant wind direction, yielding a sediment volume reduction in the embryo dune; as a counterpart, an increase in sediment volume occur because of seaward accretion due to onshore aeolian sediment supply as opposed to either a gain in height or an expansion of the dune field in an alongshore direction (Montreuil, Bullard \& Chandler, 2013a). Commonly, embryo dunes are populated by pioneer vegetation species that can cope with sand burial (Gómez et al., 2017). Initially, embryonic dunes may increase species richness, but later they may compete for space, further reducing species richness (van Puijenbroek et al., 2021).

\section{Materials \& Methods}

Study area. Along 358 kilometers of the coastline of Jalisco, México, and covering the municipalities of Puerto Vallarta, Cabo Corrientes, Tomatlán, La Huerta, and Cihuatlán, we can find different coastlines, mainly: Sandy beaches, cliffs, mangroves, and estuaries. The sandy beaches occupy approximately $181 \mathrm{~km}(50.5 \%)$ in the State and are formed by a beach followed by sand mounds or dunes.

In the embryo dunes, 29 sites were sampled: 1) Las Playitas, 2) North Aquiles Serdán, 3) Los Naranjos, 4) Aquiles Serdán, 5) Mayto, 6) Las Villas, 7) El Realito, 8) El Coco, 9) Las Peñitas (San Carlos), 10) Playón de Mismaloya, 11) North La Gloria, 12) South La Gloria, 13) La Limonera, 14) Las Peñitas, 15) North Chalacatepec, 16) South Chalacatepec, 17) La Soledad, 18) Chachalacas, 19) North Chamela, 20) South Chamela, 21) Playa Chica, 22) North E1 Tecuán, 23) South El Tecuán, 24) North Tenacatita, 25) South Tenacatita, 26) Punta Tenacatita, 27) Melaque (Laguna del Tule), 28) Isla Navidad, and 29) Rio Marabasco. These sites are located between latitudes $19.16^{\circ}$ and $20.21^{\circ}$ north and longitudes $104.61^{\circ}$ and $105.41^{\circ}$ west (Fig. 1).

Figure 1. Location of sample sites.

Map data C 2021 Esri, Garmin, GEBCO, NOAA NGDC, INEGI. 
159

160

161

162

163

164

165

166

167

168

169

170

171

172

173

174

175

176

177

178

179

180

181

182

183

184

185

186

187

188

189

190

191

192

193

194

195

196

197

198

Geomorphology classifies the study area as rocky coasts, where stretches of cliffs and rocky points alternate and are bordered by bays and thin beaches. With $62 \mathrm{~km}$ in length, Mismaloya beach is the one with the greatest continuity (SEMARNAT, 2013). The climate is predominantly warm semi-arid and warm sub-humid, with a mean annual temperature between 22 and $26^{\circ} \mathrm{C}$ and mean annual precipitation between 400 and $800 \mathrm{~mm}$. Urban and tourist use of soils represents $4 \%$ of the surface, while natural vegetation covers $96 \%$ of the territory. Nevertheless, vegetation is currently strongly impacted by extensive livestock (SEMARNAT, 2013).

Pre-field work. A geographic information system (GIS) was integrated by using the ArcGIS Desktop 10.3 software and with national open data that include the topics hydrological basins (INEGI, 2001b), land use and vegetation (INEGI, 2017b), types of soils (INEGI, 2017a), types of rocks (INEGI, 1999); communication routes, urban areas, streams, water bodies, place names and contour lines (INEGI, 1998); and climate types (INEGI, 2001a).

A digital elevation model and a shading model were generated from the contour lines (INEGI, 1998) in the ArcGIS system, with a pixel size of $20 \mathrm{~m}$. Both models were integrated into the GIS. False-color compositions with bands 3,2,1 were also generated in ArcGIS with 19 Spot-4 satellite images, with a spatial resolution of $10 \mathrm{~m}$ mono-spectral pixel, and $20 \mathrm{~m}$ multispectral pixel. The spectral resolution for band 1 (Green) is $0.50-0.59 \mu \mathrm{m}$; for band 2 (red) is $0.61-0.68$ $\mu \mathrm{m}$; for band 3 (near-infrared) is $0.78-0.89 \mu \mathrm{m}$, and for band 4 (mid-infrared) is $1.58-1.75 \mu \mathrm{m}$. The single-shot date was between January and February 2015.

Finally, relief forms were delimited and classified by using the false-color compound according to the modified physiographic method for México (Ortiz-Solorio and Cuanalo-de la Cerda, 1984).

Fieldwork. Soil sampling was made from January to March 2017, under a random stratified design, considering 1-2 sites per each interpreted topoform. Soil samples were collected $10 \mathrm{~m}$ away from the starting point of the dune, in a perpendicular direction and opposite to the beach. A $30 \times 30 \times 30 \mathrm{~cm}$ hole was made in the ground, subsequently, a representative sample of soil depth was taken from the wall of the well that faces the sea; the vegetation island effect was avoided in every case.

Data collection in each observation site included: geographical location (UTM coordinates, zone $13 \mathrm{~N})$, altitude (masl), vegetation coverage (\%), description of the topographic shape, terrain slope (\%), slope orientation, distance to the sea, identification of vegetation and land use according to the classification system used by the Mexican government for national cartography (INEGI, 2017c); phytosociological samplings according to the methodology of Braun-Blanquet (1979) and identification of flora according to Macías et al. (2019).

Peer] reviewing PDF | (2021:07:63863:1:1:NEW 25 Jan 2022) 
199

200

201

202

203

204

205

206

207

208

209

210

211

212

213

214

215

216

217

218

219

220

221

222

223

224

225

226

227

228

229

230

231

232

233

234

235

236

237

238
Laboratory. Prior to laboratory determinations, samples collected were air-dried and labeled. Lab determinations included wet and dry color with Munsell Tables, particles size (\% sand) according to the American Classification System (USDA, 2017), organic matter (\%) with the Walkley-Black procedure (van Reeuwijk, 2002), $\mathrm{pH}$ in solution 2:1, measured with a potentiometer (van Reeuwijk, 2002), electrical conductivity $\left(\mathrm{dSm}^{-1}\right)$ in saturation extract, measured with a conductivity meter (van Reeuwijk, 2002), magnetite content (\%), by separating it with a magnet, moisture retention (\%) with the gravimetric method (van Reeuwijk, 2002).

Metric variables totalized 17; 12 edaphic: moisture retention, organic matter, electrical conductivity, $\mathrm{pH}$, magnetite, gravel, very coarse sand, coarse sand, medium sand, fine sand, very fine sand, fraction finer tan very fine sand; one geographic: latitudinal gradient; two geomorphological: distance to the sea, topoform altitude; and two vegetation variables: vegetation coverage and number of plant species. The parametric variables included the color of sands in wet and dry and the orientation of the topographic shape. As complementary data, rock types and climate types were included. Finally, a table of presence/absence of plant species was integrated from species identified with the phytosociological method.

The variable latitudinal gradient was considered quantitatively not by latitudinal values per se but by ordinal values from 1 to 29 (according to the number of sample sites), assigning the value 1 to the northernmost site and 29 to the southernmost site.

Statistical and spatial analysis. For the statistical analysis, we first explored how the environmental variables are correlated with each other, using Spearman's r.

Subsequently, to identify the relationships between the environmental variables (including edaphic, geomorphological, and geographic), we used multivariate statistics; thus, two principal component analyzes (PCA) were made, the first with all the variables, to generate the matrix of anti-image correlations and to be able to select the variables with the best measures of sample adequacy, in the second PCA the number of participating variables and the number of eigenvectors was reduced, yielding an increase in the variance explained in the first two axes. Further, a cluster analysis was performed to group the sample sites to facilitate the identification and interpretation of the environments explored; to validate the congruence of the groups, an analysis of variance (ANOVA) was carried out.

The PCA and its canonical form, the redundancy analysis (RDA), are more robust than the canonical correspondence analysis (CCA) to analyze the interrelationships between the attributes of the soil and the shape of the terrain, since their behavior, in general, is more linear (Odeh, Chittleborough \& McBratney, 1991; Park \& Burt, 2002; Kim \& Yu, 2009). But, CCA is frequently recommended to analyze the relation between floristic data and environment (for

Peer) reviewing PDF | (2021:07:63863:1:1:NEW 25 Jan 2022) 
239

240

241

242

243

244

245

246

247

248

249

250

251

252

253

254

255

256

257

258

259

260

261

262

263

264

265

266

267

268

269

270

271

272

273

274

275

276

277

278

example, Kim \& Yu, 2009, in dune system). Between PCA and RDA, we decided to use PCA because, in this first stage of our project, it was not intended to distinguish between edaphic and geomorphological variables, but to directly know how environmental variables influence the presence of plant species.

The relationship between environmental variables and plant species was studied with two separate methods, first, a CCA was made to define the environment-plant relationship in the study area, and identify the proximity of the environmental variables with the plant species. On the other hand, hierarchical conglomerate analysis was made based on the presence/absence of plant species. Then, we proceeded to correlate (Pearson's $r$ ) this grouping with the environmental grouping previously obtained to validate the relationship between both cluster schemes. Once the relationship between the two groups had been validated, outstanding aspects of this relationship were described and the spatial distribution of the groups was represented on a map.

The software used to perform these analyzes was IBM SPSS Statistics 19 and XLSTAT 2021.3.1.

\section{Results}

Description of plant species and environment of the study area. From the 29 sampled sites in embryo dunes, 11 species of plants were identified, five of them ubiquitous (Fig. S1), this is present not only in the embryo dunes (Fig. 2) but also in more consolidated dunes, the remaining six species were present only in the embryo dunes (Table 1), and not consistently since in seven of the 29 sites were not present these species.

Figure 2. Exclusive plant species of embryo dunes in the study area.

a) Abronia maritima, b) Canavalia rosea, c) Okenia hypogaea, d) Pectis arenaria, e) Scaevola plumieri, f) Uniola pittieri.

Photo Credit: Miguel Ángel Macías-Rodríguez.

Table 1. Plant species identified, growth pattern, and types of dunes where they are present.

Ipomoea pes-capreae and Jouvea pilosa were the most common species (22 and 18 sites, respectively), followed by Pectis arenaria and Okenia hypogaea (11 and 9 sites, respectively). The less frequent species were Abronia maritima and Uniola pittieri, since they only occurred in three sites. The average frequency per site of ubiquitous species and of exclusive species of embryo dunes was 2.0 and 1.2 , respectively.

Regarding the environment of the sites sampled, as expected, the incipient development of soils in embryo dunes reflects a low content of organic matter, silt and clay, and moisture retention. 
279 Furthermore, as shown in Table 2, the diversity of the environments is reflected in the dispersed 280 data of the granulometry (gravel, very coarse, very fine, fine, and, fraction finer than very fine 281 sand), and other edaphic properties such as electrical conductivity, organic matter, and 282 magnetite. Non-edaphic variables are less dispersed than the edaphic ones.

283

284 285

286

287

288

289

290

291

292

293

294

295

296

297

298

299

300

301

302

303

304

305

306

307

308

309

310

311

312

313

314

315

316

317

318

Table 2. Descriptive statistics of environmental variables in embryo dunes.

The sample sites are distributed in three dune systems, a) beaches and dunes dissected by cliffs, staggered, below the continental level, an example of this are the sites Las Playitas and La Soledad (Fig. S2); b) beaches and dunes of great length, which forms high dunes and above the continental level, tends to form depressions, as is the case of the El Coco and La Limonera sites; c) beaches and dunes of variable length, tend to form beaches and wide dunes, sometimes in bar form, which derives depressions, as seen in Figure S2, North Chamela and South E1 Tecuán sites.

Relationships between environmental variables. Vegetation coverage correlated significantly with topographic, edaphic, and geographic variables (Table 3). Higher correlations were obtained with $\mathrm{pH}(\mathrm{r}=0.690, \mathrm{p}=0.001)$, fine sand $(\mathrm{r}=0.600, \mathrm{p}=0.001)$, magnetite $(0.644, \mathrm{p}=0.001)$, and latitudinal gradient $(\mathrm{r}=0.809, \mathrm{p}=0.001)$ showing that a major presence of vegetation should be expected southward the study area. Latitudinal gradient also strongly correlated with $\mathrm{pH}$ $(\mathrm{r}=0.834, \mathrm{p}=0.001)$ and with magnetite $(\mathrm{r}=0.731, \mathrm{p}=0.001)$, and with a moderate but significant coefficient with fine sand $(\mathrm{r}=0.670, \mathrm{p}=0.001)$. These correlations also indicate a geographical pattern in the spatial distribution of these edaphic variables. Significant and moderately high correlations were also obtained between soil properties: $\mathrm{pH}$ with magnetite $(\mathrm{r}=0.639, \mathrm{p}=0.001)$, $\mathrm{pH}$ with fine sand $(\mathrm{r}=0.662, \mathrm{p}=0.001)$, moisture retention with very fine sand $(\mathrm{r}=0.613, \mathrm{p}=0.001)$. The rest of the significant correlations can be seen in Table 3 .

Table 3. Correlation coefficients between environmental variables.

r: Spearman's rho correlation coefficient, $p$ : $p$-value

Grouping of embryo dunes according to environmental variability. As a by-product of the PCA, the anti-image correlation matrix allowed obtaining the Kaiser-Meyer-Olkin (KMO) sampling adequacy measures. The criterion to keep variables was $\mathrm{KMO}>0.45$, therefore distance to the sea $(\mathrm{KMO}=0.175)$, number of plant species $(\mathrm{KMO}=0.255)$, fraction finer than very fine sand $(\mathrm{KMO}=0.307)$, and gravel $(\mathrm{KMO}=0.372)$ were excluded from the analysis. For the PCA, nine variables were considered: moisture retention $(\mathrm{KMO}=0.583)$, organic matter $(\mathrm{KMO}=0.450)$, $\mathrm{pH}(\mathrm{KMO}=0.639)$, magnetite $(\mathrm{KMO}=0.613)$, very coarse sand $(\mathrm{KMO}=0.677)$, fine sand $(\mathrm{KMO}=0.847)$, latitudinal gradient $(\mathrm{KMO}=0.737)$, altitude of the topoform $(\mathrm{KMO}=0.745)$, and vegetation coverage $(\mathrm{KMO}=0.705)$. According to the Kaiser criterion, we selected the first two components (eigenvalue $>1$ ). The first component explains $52.34 \%$ of the variance and the 
319 second component $17.84 \%$, accumulating $70.18 \%$ of the total variance. The first component is 320 determined by latitudinal gradient, vegetation coverage, $\mathrm{pH}$, fine sand, magnetite, and inversely 321 by very coarse sand and altitude of the topoform. The second component was determined by 322 moisture retention and organic matter. Table 4 shows the eigenvectors of the final nine 323 environmental variables from the first two principal components.

324

325 326

327

328

329

330

331

332

333

334

335

336

337

338

339

340

341

342

343

344

345

346

347

348

349

350

351

352

353

354

355

356

357

Table 4. Principal component analysis and cluster analysis statistics.

Hierarchical cluster analysis with squared Euclidean distance $<10$, permitted to identify four groups and an atypical site. Group 1 includes nine sites; Groups 3 and 5 are integrated by eight sites each; Group 4 contains three sites, and Group 2 includes only the atypical site (Fig. S3). The scatter plot (Fig. 3) generated with the scores of the two first components, shows the distribution and proximity between groups identified in the cluster analysis. There is a statistically significant difference between groups according to the two scores, as shown by the one-way ANOVA (Table 4); F (4.24) $=28.396, \mathrm{p}=0.001$ for the first score, and $\mathrm{F}(4.24)=27.836$, $\mathrm{p}=0.001$ for the second score.

Figure 3. Scatter plot constructed with the PCA component scores.

The numbers framed within the plot correspond to the site number.

Description of the groups from environmental cluster analysis. According to dry color values (pale brown and very pale brown), the sands of Group 1 sites are mostly made up of granite and conglomerate granite ( $88.9 \%$ of sites). This group presents the lowest mean values of moisture retention, $\mathrm{pH}$, magnetite, fine sand, vegetation coverage, the number of plant species, and the highest mean values of very coarse sand and altitude of topoform (Table 5).

Table 5. Environmental characteristics and number of plant species for the groups from the cluster analysis.

$\bar{x}$ : mean; s: standard deviation; $\mathrm{n}$ : number of observations (sites).

In Group 2, which is integrated only by the atypical site, the source material is granite, light yellowish-brown color (dry color), with $5.9 \%$ of moisture retention, organic matter $0.202 \%, \mathrm{pH}$ 6.67 , magnetite $4 \%$, vegetation coverage $10 \%$ and two plant species.

Group 3 sites have a mineral fraction formed from sandstone-conglomerate (50\%) and granite $(25 \%)$. The dry sands are light brownish gray $(50 \%)$ and light yellowish brown (25\%). As can be seen in Table 5, this group has the lowest mean value in very coarse sand and the highest mean value for moisture retention and organic matter. 
358

359

360

361

362

363

364

365

366

367

368

369

370

371

372

373

374

375

376

377

378

379

380

381

382

383

384

385

386

387

388

389

390

391

392

393

394

395

396

In Group 4, the sites present a mineral fraction formed from volcanoclastics (100\%), and the sands are dark gray $(66.7 \%)$ when wet. In Table 5, it can be observed that this group presents the lowest mean value in organic matter and the highest mean values of electrical conductivity, magnetite, distance to the sea, and vegetation coverage.

The mineral fraction in sites of Group 5 is formed mainly from volcanoclastics (37.5\%) and acid tuff $(25 \%)$, the color of sands in wet are brown, greyish brown, and very dark greyish brown (75\%). This group has the lowest mean value of electrical conductivity and distance to the sea, and the highest mean values of $\mathrm{pH}$, fine sand, and the number of species.

Relationship between environmental variables and plant species. Canonical correspondence analysis resulted significant ( $\mathrm{p}$-value Montecarlo test $=0.026,500$ permutations) in the first two Axes, showing that vegetation data are related to the environmental properties data. As can be seen in Table 6, the cumulative percentage variance of species-environment relation totalizes 54.01 in the first two axes.

Table 6. Summary of canonical correspondence analysis for the first two axes at the embryo dunes of the Pacific Coast in Jalisco, México.

All bold values are significant at the level, $\mathrm{p}<0.05$.

The electrical conductivity was highly and significantly correlated (0.708) with Axis 1 , while organic matter (-0.371), very coarse sand (0.391), and orientation of the topoform $(0.456)$ correlated significantly, although with a low-value coefficient with the Axis 2.

The CCA ordination plot (Fig. 4) allows visualizing the proximity of the species with each environmental variable. Thus, the exclusive species of embryo dunes show to be the most distant from the environmental variables; good examples of this condition are Abronia maritima and Uniola pittieri (Fig. 4). However, according to the plot, the variable that can best explain the presence of Okenia hypogaea is organic matter, while the presence of Pectis arenaria is more linked to fine sand. In the case of Canavalia rosea, is the influence of fine sand, $\mathrm{pH}$, and distance to the sea, that favors the presence of this species (Fig. 4).

Figure 4. Ordination diagram that illustrates the relationships between environmental properties (lines) and plant species (dots).

Species: Abr: Abronia maritima, Aca: Acalypha monostachya, Can: Canavalia rosea, Dis: Distichlis spicata, Ipo: Ipomoea pes-capreae, Jou: Jouvea pilosa, Oke: Okenia hypogaea, Pec: Pectis arenaria, Pro: Prosopis juliflora, Sca: Scaevola plumieri, Uni: Uniola pittieri. Environment variables: alt: Altitude of the topoform, cob: Vegetation coverage, dis: Distance to the sea, lat: Latitudinal gradient, ori: Orientation of the topoform, af: Fine sand, amg: Very 
397

398

399

400

401

402

403

404

405

406

407

408

409

410

411

412

413

414

415

416

417

418

419

420

421

422

423

424

425

426

427

428

429

430

431

432

433

434

435

436

437

coarse sand, ce: Electrical conductivity, hum: Moisture retention, mg: Magnetite, mo: Organic matter, ph: $\mathrm{pH}$.

Regarding ubiquitous species, they show more interdependence with environmental variables, thereby organic matter is the most explanatory variable for the presence of Acalypha monostachya, Distichlis spicata, and Jouvea pilosa. Ipomoea pes-capreae is related to retention of moisture, $\mathrm{pH}$, and electrical conductivity. Prosopis juliflora is the only ubiquitous species that is not related to any of the environmental variables.

Table 7 shows the simple correlation of plant species with some environmental variables. It is worth mentioning that this table only includes five of the 12 variables considered in the CCA, since for the remaining seven variables no significant correlation was found $(p<0.05)$ with any plant species. It stands out that two exclusive species of embryo dunes show significant correlations; Okenia hypogaea with two non-edaphic environmental variables (Latitudinal gradient and Distance to the sea) and Uniola pittieri with two edaphic variables (Electrical conductivity and very Coarse sand). The other four exclusive species of embryo dunes did not show any significant correlation with environmental variables.

Table 7. Correlation coefficients between plant species and some environmental variables. r: Spearman's rho correlation coefficient, $p$ : p-value.

Regarding the ubiquitous species, three showed significant correlation with at least one environmental variable, Acalypha monostachya, and Jouvea pilosa, in which electrical conductivity influences the sites that these species colonize. Meanwhile, Ipomoea pes-capreae is positively influenced by the orientation of the topoform, that is, the south orientation of the topoform is favorable for it.

Grouping of embryo dunes according to plant species. Hierarchical cluster analysis with squared Euclidean distance, allowed us to identify five groups of plant species. Group 1 is composed of nine sites, Groups 2 and 3 including seven sites each, and groups 4 and 5 integrated by three sites each (Fig. S4).

As can be seen in Table 8, Group 1 is the only one that does not have a plant species that is present in all sites, it is also the group that reports the fewest species, Group 2 is dominated by the presence of Pectis arenaria; Group 3 by Okenia hypogaea; Group 4 by Scaevola plumieri, and Group 5 by Canavalia rosea. Abronia maritima is scarcely present in Groups 1, 2, and 4, while Uniola pittieri is present in Groups 1 and 5 but with little representation.

Table 8. Plant species that determined the conformation of the groups in cluster analysis.

$\mathrm{n}$ : number of observations (sites)

PeerJ reviewing PDF | (2021:07:63863:1:1:NEW 25 Jan 2022) 
438 Relationship between environmental and plant species clusters. Grouping of embryo dunes

439 by environmental variables (GVA) and by presence/absence of plant species (GEF) have a

440 significant correlation (Pearson $\mathrm{r}=0.471, \mathrm{p}=0.01$ ), which shows that there is a relationship

441 between environmental variables and plant species. Figure 5 and Figure 6 show the geographic

442 distributions of both clusters.

443

444

Figure 5. Geographic distribution of groups of sites according to environmental variables (GVA).

445

Map data (C) 2021 Esri, Garmin, GEBCO, NOAA NGDC, INEGI.

446

447

Figure 6. Geographic distribution of groups of sites according to the presence of plant species

448 (GEF).

449

450

451

Map data C 2021 Esri, Garmin, GEBCO, NOAA NGDC, INEGI.

452

Five out of nine sites of GEF 1 (with the least presence of species) are related to GVA 1 and

453

GVA 2; these groups contain the dunes with the thickest values of particles and the lowest values in the parameters that indicate fertility. These groups are found mostly in the northern portion of

454 the study area, on the open coastline, and with few dune cords. A similar condition is found in

455

456

457 GEF 2 (group predominated by Pectis arenaria); four of the seven sites coincide with GVA 1.

458

459

460

461

462

463

464

465

466

467

468

469

470

471

472

473

474

475

476

477

The Group GEF 3 (predominated by Okenia hypogaea) has a dispersed distribution and is related to all the GVA $(1,3,4,5)$. GEF 3 is formed by dunes with the highest vegetation coverage and the highest magnetite contents, it is found mainly in the southern portion of the study area, in bays with wide beaches and numerous dune ridges.

Scaevola plumieri predominates in GEF 4, with a distribution in the central part of the territory studied and it_s completely contained in GVA 3. This group shows the dunes with the highest content of organic matter as well as moisture retention capacity; it is present on the open coastline associated with lagoon systems and with numerous dune ridges. Finally, GEF 5 (with a major presence of Canavalia rosea) has a distribution in the central part of the study area and it is contained totally in GVA 5. This group has the highest $\mathrm{pH}$, the finest sand grains, and the greater presence of species, it is present in coastlines protected by bays with narrow beaches and few dune ridges.

\section{Discussion}

The high values of coefficient of variation found in diverse edaphic variables, evidence soil properties that still keep great dynamics, which is characteristic for not consolidated soils in embryo dunes (van Puijenbroek et al., 2021). In such edaphic conditions, the establishment of vegetation occurs with pioneer species or with species with a certain level of rusticity or adaptation to poor soils, which limits the number of species present (Ripley \& Pammenter, 2008; 
478 Sile et al., 2017). However, the plant communities that these species usually form are very 479 diverse in composition (species) and coverage, which is also due to the spatial variation of 480 edaphic properties (Table 1).

481

482

483

484

485

486

487

488

489

490

491

492

493

494

495

496

497

498

499

500

501

502

503

504

505

506

507

508

509

510

511

512

513

514

515

516

Environmental diversity. By the results obtained in the correlation analyses, the organic matter in the embryo dunes is azonal, therefore, it is directly related to topoform altitude (both determined by wind processes), and is inversely related to vegetation coverage. Through the transport of sea salt and sand grains, wind processes provide materials that contain various organic and inorganic components, they are the most important source of nutrients for the plant and enrichment of organic matter in the dunes (Yu, Rhem \& Kim, 2004).

Correlation analysis also reveals that when $\mathrm{pH}$, fine sand, and magnetite are increased, greater vegetation coverage is favored. Moreover, $\mathrm{pH}$, fine sand, and magnetite are negatively correlated with topoform altitude, thus vegetation coverage is expected to be greater in lower topoform altitudes. Similarly, Kim \& Yu (2009) identified $\mathrm{pH}, \mathrm{Ca}^{2+}$, and $\mathrm{Mg}^{2+}$ as explanatory variables for the presence of vegetation, and found that altitude, distance to the sea, and aspect of the slope are negatively correlated with vegetation.

Regarding the relationship soil and vegetation have, the soil must be understood as the set of its properties and not only its properties independent of each other (Hironaka, Fosberg \& Neiman, 1991). This is why soils characterization is preferably carried out with multivariate techniques. (Kim, Yu \& Park, 2008). With the grouping of sites with cluster analysis PCA, it is observed that GVA 1 and GVA 2 contrast in fertility concerning GVA 3, GVA 4, and GVA 5. While GVA 1 and GVA 2 are located in more northern and less fertile sites; GVA 3, GVA 4, and GVA 5 are distributed in more southern and more fertile places. According to the correlation analysis, this condition does not depend on the moisture retention index, nor the content of organic matter, as might be supposed, but on the geological material that gave rise to the sands, which determine their granulometry, pH, and content of magnetite (Weil \& Brady, 2017).

In the study area, geological materials most susceptible to physical weathering (plutonic) are found in the northern portion, while those susceptible the most to chemical weathering (volcanic) are located in the southern portion, and in the central region, there is a combination of both geological materials; hence the correlation analysis of the latitudinal gradient reflects the material that gave rise to the dune sands. Consequently, $\mathrm{pH}$, magnetite, and fine sand increase from north to south, and coarse sand decreases. Volcanic materials produce sands with a greater capacity to support plants (evidenced by the percentage of vegetation coverage and number of plant species) than plutonic materials (Weil \& Brady, 2017). On the other hand, the hardness of geological materials and their age of exposure to weathering strongly influences the relief conformation. Young materials, such as the plutonic rocks in the north of the study area, 
517 determine abrupt reliefs, while older materials with less hardness, like the volcanic rocks in the 518 southern portion of the region, produce reliefs with gentler slopes (SGM, 2017).

519

520

521

522

523

524

525

526

527

528

529

530

531

532

533

534

535

536

537

538

539

540

541

542

543

544

545

546

547

548

549

550

551

552

553

554

555

556
Relationship between environmental variables and plant species. Variance explained in the first two axes from the CCA is relatively low in comparison to other studies (Kim y Yu, 2009) but sufficient to demonstrate the existence of a relationship between environment and plant species in the ecosystems of embryo dunes. This can be explained by considering the nature of the present investigation, which considered sampling soils in a great territorial extension ( 29 sites distributed in $181 \mathrm{~km}$ of littoral); besides, samples were taken in incipient soils, where edaphic properties are just developing (Miller, Gornish \& Buckley, 2010).

In general, the plant species exclusive of embryo dunes are little dependent on environmental properties, because they are the pioneer species to colonize the soils in their early stages of formation, and have physiological adaptations that allow them to grow in a difficult environment, such as prostrate habit to avoid strong winds, deep tap roots to obtain available moisture, waxy leaves to retain moisture and withstand winds, and high salt tolerance (Ripley \& Pammenter, 2008). Abronia maritima y Uniola pittieri showed to be very good examples of this condition. The other four exclusive species of embryo dunes show an incipient edaphic dependence, but it is not clear how this relationship occurs.

Plant species exclusive of embryo dunes play a key role in stabilizing the dune, and the accumulation of finer particles such as fine and very fine sand, silts, organic matter, and salt, which are carried by the wind processes, which constitute the most important source of nutrients for the plant and enrichment of organic matter in the dunes (Yu, Rhem \& Kim, 2004). As this process of sedimentation of fine particles occurs, suitable conditions are generated for the ubiquitous species to arrive (Pan, Zhang \& Li, 2016; Wang, Chu \& Daryanto, 2019; van Puijenbroek et al., 2021).

\section{Cluster analysis by presence/absence of plant species reveals that some species have a} predilection for poorer edaphic conditions, others instead prefer more developed edaphic conditions. Abronia maritima, Uniola pittieri, and Pectis arenaria tend to be distributed in embryo dunes with thicker sands and less edaphic development, but not Okenia hypogaea, Canavalia rosea, and Scaevola plumieri, which tend to predominate in embryo dunes with higher content of magnetite, organic matter, and fine sands, as well as higher values of $\mathrm{pH}$ and moisture retention. Angiolini, Bonari \& Landi (2018) mention that pioneer species of embryo dunes show a maximum probability of occurrence at low values of total organic carbon, while the ubiquitous species show a contrary trend.

The complex interrelations between geomorphology, soil, and vegetation are key factors in the formation of ecological patterns and processes (Landi, Ricceri \& Angiolini, 2012). This

Peer] reviewing PDF | (2021:07:63863:1:1:NEW 25 Jan 2022) 
557 complexity can be understood as a chain of causal connections between geomorphological

558

559

560

561

562

563

564

565

566

567

568

569

570

571

572

573

574

575

576

577

578

579

580

581

582

583

584

585

586

587

588

589

590

591

592

593

594

595

596

phenomena, soil conditions, and vegetation patterns (Moreno-Cassasola, 1982; Kim \& Yu, 2009; van Puijenbroekab et al., 2021). The embryo dunes of the coast of Jalisco, México, show a complex interaction between plants and ambient, which is validated by the relatively low but significant explanation of the variance with the CCA and the moderately low but significant correlation between environmental grouping and plant species grouping. Similar results have been obtained by other authors, who explain them in terms of the complexity of the interactions that occur within the coastal ecosystems (Ciccarelli, 2014; Ruocco et al., 2014; Angiolini, Bonari \& Landi, 2018).

\section{Conclusions}

The embryo dunes of the Pacific coast in the state of Jalisco, Mexico, are incipient soils with variable parameters, which limit the number of plant species that can be established, but favor plant communities of variable composition, which in turn generate diverse landscapes.

Despite the youth of the soils of the embryo dunes, three edaphic variables were observed to be closely related: $\mathrm{pH}$, fine sand, and magnetite, which in turn are related to the vegetation cover, thus, these variables are the main ones responsible for variability in soil fertility. Although for biologists the dunes are referred to just as "substrate", in Edaphology the dunes are considered as soils, therefore the soils of the studied area are classified as Arenosols (IUSS, 2015).

In these Arenosols, the source of organic matter is transported by the wind together with other particles, it is not the result of in situ edaphic processes, for this reason, it is not related to the rest of the edaphic properties, instead, it is directly related to the height of the topoform, and inversely associated with the vegetation cover.

Magnetite content is evident in regional dune soils. Therefore, magnetite should be considered an important variable in forthcoming dune soils research.

Multivariate analysis (PCA and Cluster analysis) and the linear correlations showed that $\mathrm{pH}$, fine sand, and magnetite influence the soil fertility of the embryo dunes of the Jalisco Coast, but not organic matter or moisture retention. These three edaphic properties are related to the regional geological source material, thus, is the most influential soil-forming factor in the incipient soils of the region.

From an edaphic perspective, it was possible to distinguish the distribution pattern of the exclusive species of embryo dunes concerning the ubiquitous species of coastal dunes, the former being less dependent on the edaphic conditions, and the latter being the most dependent on environmental conditions, especially on edaphic conditions. We assume that there is a plant 
597 succession between them, thus, the exclusive species of embryo dunes could be considered as

598 pioneers. In addition to this, the PCA and the cluster analysis show that among the exclusive

599 species of embryo dunes, some species prefer conditions of low fertility, while others prefer a

600 higher degree of fertility.

601

602 Even in the context of its incipient edaphic and floristic development, regional embryo dune soils

603 glimpse an interaction between plants, relief, and soil, which is reflected in the results of the two

604 methods used for its understanding.

605

606 The development of this study made it possible to document the first report supported with 607 research data on the relationship between environmental properties and plant species in the 608 coastal dunes of Jalisco, México.

609

610

\section{Acknowledgments}

611

612

The authors express their gratitude to Roberto Esparza and Rafael Hernández, who collaborated

613 in the fieldwork. We also thank Isaías Pedroza and Benjamín Hinojos for their participation in

614 the lab determinations.

615

616

\section{References}

617

618 Acosta ATR, Carranza ML \& Izzi CF. 2009. Are there habitats that contribute best to plant 619 species diversity in coastal dunes? Biodiversity and Conservation 18(4): 1087-1098.

620 https://doi.org/10.1007/s10531-008-9454-9

621

622 Acosta ATR, Stanisci A, Ercole S \& Blasi C. 2003. Sandy coastal landscape of the Lazio region

623 (Central Italy). Phytocoenologia 33 (4), 715e726. DOI:10.1127 / 0340-269X / 2003 / 0033-0715

624

625

Angiolini C, Bonari G \& Landi M. 2018. Focal plant species and soil factors in Mediterranean

626 coastal dunes: An undisclosed liaison? Estuarine, Coastal and Shelf Science 211: 248-258.

627 https://doi.org/10.1016/j.ecss.2017.06.001

628

629

Biel RG, Hacker SD \& Ruggiero P. 2019. Elucidating coastal foredune ecomorphodynamics in 630 the U.S. Pacific Northwest via Bayesian networks. Journal of Geophysical Research: Earth

631 Surface 124, 1919-1938. https://doi.org/10.1029/2018JF004758.

632

633 Braun-Blanquet J. 1979. Fitosociología. Bases para el estudio de las comunidades vegetales. 634 Blume Ediciones. Madrid.

635 
636 Carboni, M, Santoro R \& Acosta ATR. 2011. Dealing with scarce data to understand how 637 environmental gradients and propagule pressure shape fine-scale alien distribution patterns on 638 coastal dunes. Journal of Vegetation Science. 22 (5), 751e765. https://doi.org/10.1111/j.1654$639 \underline{1103.2011 .01303 . x}$

640

641 Ciccarelli, D. 2014. Mediterranean coastal sand dune vegetation: influence of natural and 642 anthropogenic factors. Environmental Management 54 (2), 194-204.doi:10.1007 / s00267-014$643 \underline{0290-2}$

644

645 Forey E, Chapelet B, Vitasse Y, Tilquin M, Touzard B \& Michalet R. 2008. The relative 646 importance of disturbance and environmental stress at local and regional scales in French coastal

647 dunes. Journal of Vegetation Science 19 (4), 493e502. https://doi.org/10.3170/2008-8-18392

648

649 Gao J, Luo Y, Wei Y, Huang Y, Zhang H \& He W. 2019. Effect of aridity and dune type on 650 rhizosphere soil bacterial communities of Caragana microphylla in desert regions of northern 651 China. PLoS ONE 14(10): e0224195. https://doi.org/10.1371/journal.pone.0224195.

652

653 Gómez JF, Byrne ML, Hamilton J, \& Isla F. 2017. Historical coastal evolution and dune 654 vegetation in Isla Salamanca National Park, Colombia. Journal of Coastal Research 33(3), 632655641 .

656

657 Hironaka M, Fosberg MA, \& Neiman KE Jr. 1991. The relationship between soils and

658 vegetation. In: Proceedings-Management and productivity of western Montane. Harvey AE, 659 Neuenschwander LF. Compilers. The University of Idaho. Boise, ID, USA.

660

661

662

663 INEGI. 1998. Conjunto de datos vectoriales topográficos escala 1:50,000. Instituto nacional de Estadística y Geografía. Aguascalientes, México. Available at

664

665 https://www.inegi.org.mx/temas/topografia/(accessed May 2016).

666 Estadística y Geografía. Aguascalientes, México. Available at

667 https://www.inegi.org.mx/temas/geologia/(accessed May 2016).

668

669 INEGI. 2001a. Conjunto de datos vectoriales de climatología escala 1:250,000. Instituto nacional 670 de Estadística y Geografía. Aguascalientes, México. Available at

671 https://www.inegi.org.mx/temas/climatologia/(accessed May 2016).

672

673 INEGI. 2001b. Conjunto de datos vectoriales de hidrología escala 1:250,000. Instituto nacional

674 de Estadística y Geografía. Aguascalientes, México. Available at

675 https://www.inegi.org.mx/temas/hidrologia/(accessed May 2016). 
676

677 INEGI. 2017a. Conjunto de datos vectoriales de edafología serie 4, escala 1:250,000. Instituto

678 nacional de Estadística y Geografía. Aguascalientes, México. Available at

679 https://www.inegi.org.mx/temas/edafologia/ (accessed May 2016).

680

681 INEGI. 2017b. Conjunto de datos vectoriales de uso del suelo y vegetación serie 6, escala

682 1:250,000. Instituto nacional de Estadística y Geografía. Aguascalientes, México. Available at

683 https://www.inegi.org.mx/temas/usosuelo/(accessed May 2016).

684

685 INEGI. 2017c. Guía para la interpretación de cartografía. Uso del suelo y vegetación. Instituto

686

687

688 nacional de Estadística y Geografía. Aguascalientes, México.

689

IUSS Working Group WRB, 2015. World Reference Base for Soil Resources 2014, Update

690

2015. International Soil Classification System for Soil Nomenclature and Soil Map Legend

691

692 Creation. World Soil Resources Reports 106. FAO, Rome.

693

Jiménez-Orocio O, Espejel I, \& Martínez ML. 2015. La investigación científica sobre dunas costeras de México: origen, evolución y retos. Revista Mexicana de Biodiversidad 86(2): 486-

694 507. https://doi.org/10.1016/j.rmb.2015.04.022.

695

696

Kim D \& Yu KB. 2009. A conceptual model of coastal dune ecology synthesizing spatial

697

698 gradients of vegetation, soil, and geomorphology. Plant Ecology 202, 135.

699

700

701 https://doi.org/10.1007/s11258-008-9456-4

Kim D, Yu KB \& Park SJ. 2008. Identification and visualization of complex spatial patterns of coastal dune soil properties using GIS-based terrain analysis and geostatistics. Journal of Coastal

702

703

704 Research 24(sp3):50-60. https://doi.org/10.2112/06-0721.1

705

Kooijman, A, Morriën E, Jagers op Akkerhuis G, Missong A, Bol R, Klumpp E, van Hall R, van 706 Til M, Kalbitz K \& Bloem J. 2020. Resilience in coastal dune grasslands: $\mathrm{pH}$ and soil organic matter effects on P nutrition, plant strategies, and soil communities. Ecosphere 11(5): e03112.

707 https://doi.org/10.1002/ecs2.3112.

708

709

Landi M, Ricceri C \& Angiolini C. 2012. Evaluation of dune rehabilitation after 95 years by 710 comparison of vegetation in disturbed and natural sites. Journal of Coastal Research 28(5):

711 1130-1141. https://doi.org/10.2112/JCOASTRES-D-11-00056.1

712

713 Li Y, Chen Y, Wang X, Niu Y \& Lian J. 2017. Improvements in soil carbon and nitrogen

714 capacities after shrub planting to stabilize sand dunes in Chinas's Horqin sandy land.

715 Sustainability 9: 662. https://doi.org/10.3390/su9040662. 
716

717 Macías-Rodríguez MA, Ballesteros-Aguirre CE, Frías-Ureña HG \& Contreras-Rodríguez SH.

718 2019. Flora de las dunas costeras de Jalisco. Universidad de Guadalajara. Guadalajara, México.

719

720

721

722

723

724

725

726

727

728

729

730

731

732

733

734

735

736

737

738

739

740

741

742

743

744

745

746

747

748

749

750

751

752

753

754

755

Martinez ML, Hesp PA \& Gallego-Fernández JB. 2013. Coastal Dunes: Human impact and need for restoration. In Restoration of Coastal Dunes; Springer: Berlin, Germany.

Martínez ML \& Valverde MT. 1992. Las dunas costeras. Ciencias, 26: 34-42.

Miller TE, Gornish ES \& Buckley HL. 2010. Climate and Coastal Dune Vegetation:

Disturbance, Recovery and Succession. Plant Ecology, 206, 97.https://doi.org/10.1007/s11258$\underline{009-9626-\mathrm{Z}}$

Montreuil AL, Bullard JE \& Chandler JH, 2013a. Detecting seasonal variations in embryo dune morphology using a terrestrial laser scanner. In: Conley, D.C., Masselink, G., Russell, P.E. \& O’Hare, T.J. (eds.), Proceedings 12th International Coastal Symposium (Plymouth, England), Journal of Coastal Research, Special Issue No. 65, pp. 1313- 1318.

Montreuil AL, Bullard JE, Chandler JH, \& Millett J. 2013b. Decadal and seasonal development of embryo dunes on an accreting macrotidal beach: North Lincolnshire, UK. Earth Surface

Processes and Landforms, 38(15): 1851-1868. https://doi.org/10.1002/esp.3432.

Moreno-Casasola P. 1982. Ecología de la vegetación de dunas costeras: factores físicos. Biótica 7(4): 577-602.

Odeh IOA, Chittleborough DJ \& McBratney AB. 1991. Elucidation of soil-landform interrelationships by canonical ordination analysis. Geoderma 49: 1-32.

https://doi.org/10.1016/0016-7061(91)90089-C

Ortiz-Solorio CA \& Cuanalo de la Cerda HE. 1984. Metodología del levantamiento fisiográfico: Un sistema de clasificación de tierras. Colegio de Postgraduados. Chapingo, México.

Pan Y, Zhang H \& Li X. 2016. Effects of sedimentation on soil physical and chemical properties and vegetation characteristics in sand dunes at the Southern Dongting Lake region, China. Sci Rep 6, 36300 (2016). https://doi.org/10.1038/srep36300.

Park SJ \& Burt TP. 2002. Identification and characterization of pedogeomorphological processes on a hillslope. Soil Science Society of America Journal 66: 1897-1910.

https://doi.org/10.2136/sssaj2002.1897 
756 Provoost S, Jones MLM \& Edmondson SE. 2011. Changes in landscape and vegetation of

757 coastal dunes in northwest Europe: A review. Journal of Coastal Conservation 15: 207-226.

758

759 Regüés D, Badía D, Echeverría MT, Gispert M, Lana-Ranault N, León J, Nadal-Romero E, 760 Pardini G \& Serrano-Muela P. 2017. Analysing the effect of land use and vegetation coverage on 761 soil infiltration in three constrasting environments in northeast Spain. Geographical Research 762 Letters 43(1): 141-169. DOI: https://doi.org/10.18172/cig.3164

763

764 Ripley BS \& Pammenter NW. 2008. Physiological characteristics of coastal dune pioneer 765 species from the Eastern Cape, South Africa, in relation to stress and disturbance. In:

766 Martínez ML, Psuty NP (eds) Coastal Dunes. Ecological Studies, vol 171. Springer, Berlin, 767 Heidelberg. https://doi.org/10.1007/978-3-540-74002-5 9.

768

769

Ruocco M, Bertoni D, Sarti G, Ciccarelli D. 2014. Mediterranean coastal dune systems: which

770

771 abiotic factors have the most influence on plant communities? Estuarine, Coastal and Shelf Science 149, 213e222. https://doi.org/10.1016/j.ecss.2014.08.019

772

773

774

Schwarz C, Brinkkemper J \& Ruessink G. 2019. Feedbacks between biotic and abiotic processes

775

776

777

778

779

780

781

782

783

784

785

786

787

788

789

790 governing the development of foredune blowouts: A review. Journal of Marine Science and Engineering 7, 2; doi:10.3390/jmse7010002.

SEMARNAT (Secretaría de Medio Ambiente y Recursos Naturales). 2013. Manejo de ecosistemas de dunas costeras, criterios ecológicos y estrategias. México, México.

SGM (Servicio Geológico Mexicano). 2017. Rocas ígneas. Available at https://www.sgm.gob.mx/Web/MuseoVirtual/Rocas/Rocas-igneas.html (accessed 11 January 2021).

Šile U, Caković D, Küzmič F \& Stešević D. 2017. Trampling impact on vegetation of embryonic and stabilised sand dunes in Montenegro. Journal of Coastal Conservation, 21(1): 15-21.

http://www.jstor.org/stable/45046617.

Torres-Guerrero CA, Etchevers B JD, Fuentes-Ponce MH, Govaerts B, De León-González F, Herrera JM. 2013. Influence of the Roots on Soil Aggregation. Terra Latinoamericana 31(1): $71-84$.

791

792

793

USDA. 2017. Soil survey manual, Handbook 18. Soil Science Division, United States

794 
795

796

797

798

799

800

801

802

803

804

805

806

807

808

809

810

811

812

813

814

815

816

817

818

819

820

821

822

823

824

825

826

827

828

829

830

van Puijenbroek MEB, Limpens J, de Groot AV, Riksen MJPM, Gleichman M, Slim PA, van Dobben HF, \& Berendse F. 2017. Embryo dune development drivers: beach morphology, growing season precipitation, and storms. Earth Surface Processes and Landforms 42(11): 17331744. https://doi.org/10.1002/esp.4144.

van Puijenbroek MEB, van den Dool RT, Koppenaal EC, Smit C, Berendse F, Limpensa J \& Bakkerd JP. 2021. Green beach vegetation dynamics explained by embryo dune development. Basic and Applied Ecology 56 (2021) 45 57. https://doi.org/10.1016/j.baae.2021.06.003

van Reeuwijk LP. 2002. Procedures for soil analysis. Technical Paper 9. 6th Ed. ISRIC-FAO. Wageningen, Netherlands.

Wang Y, Chu L, Daryanto S, Lü L, Ala M, \& Wang L. 2019. Sand dune stabilization changes the vegetation characteristics and soil seed bank and their correlations with environmental factors. Science of the Total Environment 648: 500-507.

https://doi.org/10.1016/j.scitotenv.2018.08.093.

Weil R, \& Brady N. 2017. The Nature and Properties of Soils. 15th edition. Prentice Hall. USA. Willis A, Harris PC, Rodrigues B \& Sparks T. 2016. Primary sand-dune plant community and soil properties during the west-coast India monsoon. European Journal of Ecology. 2(1): 60-71. https://doi.org/10.1515/eje-2016-0007.

Yu KB, Rhew HS, \& Kim SH. 2004. Aeolian sand as a nutrient carrier into the coastal dunefield. Paper presented at the 30th Congress of International Geographical Union, Glasgow, Scotland, 15-20 August 2004.

Zuo X, Zhao X, Zhao H, Zhang T, Guo Y, Li Y, \& Huang Y. 2009. Spatial heterogeneity of soil properties and vegetation-soil relationships following vegetation restoration of mobile dunes in Horqin Sandy Land, Northern China. Plant and Soil 318: 153-167. DOI:10.1007/s11104-008$\underline{9826-7}$

Zuo X, Zhao H, Zhao X, Zhang T, Guo Y, Li Y, \& Luo Y. 2008. Plant distribution at the mobile dune scale and its relevance to soil properties and topographic features. Environmental Geology 54: 1111-1120. https://doi.org/10.1007/s00254-007-1104-0

Peer) reviewing PDF | (2021:07:63863:1:1:NEW 25 Jan 2022) 


\section{Table 1 (on next page)}

Plant species identified, growth pattern, and types of dunes where they are present. 


\begin{tabular}{|l|l|l|l|}
\hline \multicolumn{1}{|c|}{ Species } & \multicolumn{1}{|c|}{$\begin{array}{c}\text { Growth } \\
\text { pattern }\end{array}$} & \multicolumn{1}{c|}{ Distribution } & \multicolumn{1}{c|}{ Sites where it is present } \\
\hline Prosopis juliflora & Shrub & Ubiquitous & $1,10,16,17,22,24$ \\
\hline Canavalia rosea & Climbing plant & $\begin{array}{l}\text { Exclusive to embryo } \\
\text { dunes }\end{array}$ & $16,17,18,21$ \\
\hline Abronia maritima & Herb & $\begin{array}{l}\text { Exclusive to embryo } \\
\text { dunes }\end{array}$ & $9,12,15$ \\
\hline $\begin{array}{l}\text { Acalypha } \\
\text { monostachya }\end{array}$ & Herb & Ubiquitous & $5,22,24,28$ \\
\hline $\begin{array}{l}\text { Ipomoea pes- } \\
\text { capreae }\end{array}$ & Herb & Ubiquitous & $\begin{array}{l}2,3,4,8,9,10,11,12,13,14,16,17, \\
18,19,21,22,23,25,26,27,28,29\end{array}$ \\
\hline Okenia hypogaea & Herb & $\begin{array}{l}\text { Exclusive to embryo } \\
\text { dunes }\end{array}$ & $5,8,16,19,20,26,27,28,29$ \\
\hline Pectis arenaria & Herb & $\begin{array}{l}\text { Exclusive to embryo } \\
\text { dunes }\end{array}$ & $5,7,9,10,12,13,18,19,21,22,25$ \\
\hline Scaevola plumieri & Herb & $\begin{array}{l}\text { Exclusive to embryo } \\
\text { dunes }\end{array}$ & $11,12,13,16$ \\
\hline Distichlis spicata & Grass & Ubiquitous & $7,11,12,13,19,22,24,28$ \\
\hline Jouvea pilosa & Grass & $\begin{array}{l}\text { Ubiquitous } \\
2,3,4,5,6,8,9,13,16,17,20,21,22, \\
23,24,26,27,28\end{array}$ \\
\hline Uniola pittieri & Grass & $\begin{array}{l}\text { Exclusive to embryo } \\
\text { dunes }\end{array}$ & $14,15,18$ \\
\hline
\end{tabular}

1 
Table 2 (on next page)

Descriptive statistics of environmental variables in embryo dunes. 
1

\begin{tabular}{|c|c|c|c|c|c|c|c|}
\hline Variable & $\mathbf{N}$ & Minimum & Maximum & Range & Mean & $\begin{array}{l}\text { Standard } \\
\text { Deviation }\end{array}$ & $\begin{array}{c}\text { Coefficient } \\
\text { of variation }\end{array}$ \\
\hline $\begin{array}{l}\text { Moisture retention } \\
(\%)\end{array}$ & 29 & 1.2 & 6.4 & 5.2 & 3.1 & 1.481 & 0.48 \\
\hline Organic matter $(\%)$ & 29 & 0.0000 & 0.2725 & 0.2725 & 0.0718 & 0.065 & 0.91 \\
\hline $\begin{array}{l}\text { Electrical } \\
\text { conductivity }\left(\mathrm{dSm}^{-1}\right)\end{array}$ & 29 & 0.05 & 4.04 & 3.99 & 0.88 & 1.036 & 1.18 \\
\hline $\mathrm{pH}$ & 29 & 6.23 & 8.66 & 2.43 & 7.36 & 0.629 & 0.09 \\
\hline Magnetite (\%) & 29 & 1.4 & 33.8 & 32.4 & 11.7 & 9.180 & 0.78 \\
\hline Gravel (\%) & 29 & 0.0 & 3.2 & 3.2 & 0.4 & 0.740 & 1.87 \\
\hline Very coarse sand $(\%)$ & 29 & 0.0 & 71.5 & 71.5 & 11.3 & 18.843 & 1.67 \\
\hline Coarse sand $(\%)$ & 29 & 0.0 & 75.1 & 75.1 & 30.6 & 23.627 & 0.77 \\
\hline Medium sand (\%) & 29 & 2.9 & 90.9 & 88.0 & 52.1 & 29.592 & 0.57 \\
\hline Fine sand $(\%)$ & 29 & 0.0 & 18.8 & 18.8 & 5.0 & 4.415 & 0.88 \\
\hline Very fine sand (\%) & 29 & 0.0 & 1.4 & 1.4 & 0.3 & 0.333 & 1.27 \\
\hline $\begin{array}{l}\text { Fraction finer tan } \\
\text { very fine sand }\end{array}$ & 29 & 0.0 & 1.0 & 1.0 & 0.3 & 0.266 & 0.87 \\
\hline Latitudinal gradient & 29 & 1.0 & 29.0 & 28.0 & 15.0 & 8.515 & 0.57 \\
\hline Distance to sea (m) & 29 & 35.7 & 173.8 & 138.0 & 72.5 & 28.998 & 0.40 \\
\hline Topoform altitude(m) & 29 & 5.0 & 22.0 & 17.0 & 11.2 & 4.473 & 0.40 \\
\hline $\begin{array}{l}\text { Vegetation coverage } \\
(\%)\end{array}$ & 29 & 5.0 & 70.0 & 65.0 & 30.0 & 21.547 & 0.72 \\
\hline $\begin{array}{l}\text { Number of plant } \\
\text { species }\end{array}$ & 29 & 1.0 & 6.0 & 5.0 & 3.2 & 1.391 & 0.44 \\
\hline
\end{tabular}




\section{Table 3(on next page)}

Correlation coefficients between environmental variables.

$r$ : Spearman's rho correlation coefficient, $p$ : $p$-value. 
1

\begin{tabular}{|c|c|c|c|c|c|c|c|c|c|c|c|c|}
\hline & & $\begin{array}{l}\text { Organic } \\
\text { matter }\end{array}$ & $\begin{array}{c}\text { Electrical } \\
\text { conductivity }\end{array}$ & $\mathrm{pH}$ & $\begin{array}{l}\text { Very } \\
\text { coarse } \\
\text { sand }\end{array}$ & $\begin{array}{l}\text { Fine } \\
\text { sand }\end{array}$ & Magnetite & $\begin{array}{l}\text { Altitude } \\
\text { of the } \\
\text { topoform }\end{array}$ & $\begin{array}{l}\text { Vegetation } \\
\text { coverage }\end{array}$ & $\begin{array}{l}\text { Distance } \\
\text { to the } \\
\text { sea }\end{array}$ & $\begin{array}{l}\text { Moisture } \\
\text { retention }\end{array}$ & $\begin{array}{l}\text { Orientation } \\
\text { of the } \\
\text { topoform }\end{array}$ \\
\hline \multirow{2}{*}{$\begin{array}{l}\text { Latitudinal } \\
\text { gradient }\end{array}$} & $\mathrm{r}$ & -.324 & -.187 & .834 & -.466 & .670 & .731 & -.522 & .809 & -.329 & .285 & -.318 \\
\hline & $\mathrm{p}$ & .087 & .332 & .000 & .011 & .000 & .000 & .004 & .001 & .081 & .134 & .093 \\
\hline \multirow{2}{*}{$\begin{array}{l}\text { Organic } \\
\text { matter }\end{array}$} & $\mathrm{r}$ & & -.062 & -.332 & .114 & -.108 & -.190 & .468 & -.455 & -.040 & .201 & -.155 \\
\hline & $\mathrm{p}$ & & .749 & .079 & .556 & .578 & .324 & .010 & .013 & .837 & .296 & .423 \\
\hline \multirow{2}{*}{$\begin{array}{l}\text { Electrical } \\
\text { conductivity }\end{array}$} & $\mathrm{r}$ & & & -.242 & .121 & -.281 & -.105 & .014 & -.092 & .185 & -.143 & -.277 \\
\hline & $\mathrm{p}$ & & & .205 & .533 & .139 & .586 & .941 & .636 & .336 & .458 & .146 \\
\hline \multirow{2}{*}{$\mathrm{pH}$} & $r$ & & & & -.480 & .662 & 639 & -.472 & .690 & -.310 & .241 & .334 \\
\hline & $\mathrm{p}$ & & & & .008 & .000 & .000 & .010 & .001 & .102 & .207 & .076 \\
\hline \multirow{2}{*}{$\begin{array}{l}\text { Very } \\
\text { coarse } \\
\text { sand } \\
\end{array}$} & $\mathrm{r}$ & & & & & -.682 & -.330 & .199 & -.519 & -.394 & -.540 & -.400 \\
\hline & $\mathrm{p}$ & & & & & .000 & .080 & .301 & .004 & .034 & .002 & .032 \\
\hline \multirow{2}{*}{ Fine sand } & $\mathrm{r}$ & & & & & & .419 & -.247 & .600 & -.016 & .513 & .547 \\
\hline & $\mathrm{p}$ & & & & & & .024 & .196 & .001 & .934 & .004 & .002 \\
\hline \multirow{2}{*}{ Magnetite } & $\mathrm{r}$ & & & & & & & -.454 & .644 & -.195 & .241 & .214 \\
\hline & $\mathrm{p}$ & & & & & & & .013 & .000 & .310 & .209 & .264 \\
\hline \multirow{2}{*}{$\begin{array}{l}\text { Altitude of } \\
\text { the } \\
\text { topoform }\end{array}$} & $r$ & & & & & & & & -.559 & .315 & -.123 & -.175 \\
\hline & $\mathrm{p}$ & & & & & & & & .002 & .096 & .526 & .363 \\
\hline \multirow{2}{*}{$\begin{array}{l}\text { Vegetation } \\
\text { coverage }\end{array}$} & $\mathrm{r}$ & & & & & & & & & -.035 & .224 & .415 \\
\hline & $\mathrm{p}$ & & & & & & & & & .857 & .243 & .025 \\
\hline \multirow{2}{*}{$\begin{array}{l}\text { Distance } \\
\text { to the sea }\end{array}$} & $\mathrm{r}$ & & & & & & & & & & -.040 & .072 \\
\hline & $\mathrm{p}$ & & & & & & & & & & .835 & .711 \\
\hline \multirow{2}{*}{$\begin{array}{l}\text { Moisture } \\
\text { retention }\end{array}$} & $\mathrm{r}$ & & & & & & & & & & & .403 \\
\hline & $\mathrm{p}$ & & & & & & & & & & & .030 \\
\hline
\end{tabular}

2 


\section{Table 4(on next page)}

Principal component analysis and cluster analysis statistics. 


\begin{tabular}{|c|c|c|}
\hline & Principal component 1 & Principal component 2 \\
\hline \multicolumn{3}{|c|}{ Variance Explained } \\
\hline$\%$ of Variance & 52.340 & 17.838 \\
\hline Cumulative $\%$ & 52.340 & 70.178 \\
\hline \multicolumn{3}{|c|}{ Eigenvectors } \\
\hline Latitudinal gradient & 0.915 & -0.087 \\
\hline Organic matter & -0.401 & 0.679 \\
\hline $\mathrm{pH}$ & 0.867 & -0.072 \\
\hline Very coarse sand & -0.669 & -0.469 \\
\hline Fine sand & 0.781 & 0.399 \\
\hline Magnetite & 0.753 & -0.112 \\
\hline Moisture retention & 0.431 & 0.712 \\
\hline Vegetation coverage & 0.879 & -0.181 \\
\hline Altitude of the topoform & -0.616 & 0.446 \\
\hline \multicolumn{3}{|c|}{ ANOVA } \\
\hline \multicolumn{3}{|l|}{ Between Groups } \\
\hline Sum of squares & 23.116 & 23.035 \\
\hline $\mathrm{df}$ & 4 & 4 \\
\hline Mean Square & 5.779 & 5.759 \\
\hline $\mathrm{F}$ & 28.396 & 27.836 \\
\hline Sig. & 0.001 & 0.001 \\
\hline \multicolumn{3}{|l|}{ Within Groups } \\
\hline Sum of squares & 4.884 & 4.965 \\
\hline $\mathrm{df}$ & 24 & 24 \\
\hline Mean Square & 0.204 & 0.207 \\
\hline
\end{tabular}




\section{Table 5 (on next page)}

Environmental characteristics and number of plant species for the groups from the cluster analysis.

$\mathrm{x}$ : mean; s: standard deviation; $\mathrm{n}$ : number of observations (sites). 


\begin{tabular}{|c|c|c|c|c|c|c|c|c|c|}
\hline \multirow{2}{*}{ Variable } & \multicolumn{2}{|c|}{$\begin{array}{c}\text { Group } 1 \\
(n=9)\end{array}$} & \multirow{2}{*}{$\begin{array}{c}\text { Group } 2 \\
(\mathbf{n}=\mathbf{1}) \\
\bar{x}\end{array}$} & \multicolumn{2}{|c|}{$\begin{array}{c}\text { Group } 3 \\
(n=8)\end{array}$} & \multicolumn{2}{|c|}{$\begin{array}{c}\text { Group } 4 \\
(n=3)\end{array}$} & \multicolumn{2}{|c|}{$\begin{array}{c}\text { Group } 5 \\
(n=8)\end{array}$} \\
\hline & $\bar{x}$ & $\mathrm{~s}$ & & $\bar{x}$ & $\mathrm{~s}$ & $\bar{x}$ & $\mathrm{~s}$ & $\bar{x}$ & $\mathrm{~s}$ \\
\hline Moisture retention & 1.94 & 0.98 & 5.97 & 4.13 & 0.99 & 1.90 & 0.72 & 3.39 & 1.30 \\
\hline Organic matter & 0.07 & 0.04 & 0.21 & 0.12 & 0.07 & 0.02 & 0.03 & 0.03 & 0.03 \\
\hline Electrical conductivity & 1.02 & 0.82 & 0.08 & 0.91 & 1.11 & 1.06 & 0.96 & 0.73 & 1.37 \\
\hline $\mathrm{pH}$ & 6.78 & 0.33 & 6.67 & 7.40 & 0.47 & 7.74 & 0.83 & 7.92 & 0.34 \\
\hline Magnetite & 6.47 & 9.00 & 4.00 & 11.54 & 8.44 & 22.07 & 10.29 & 14.94 & 6.43 \\
\hline Very coarse sand & 28.33 & 24.31 & 1.40 & 1.35 & 1.73 & 15.93 & 20.32 & 1.62 & 2.78 \\
\hline Fine sand & 1.38 & 1.82 & 3.80 & 6.12 & 3.06 & 2.27 & 2.57 & 9.20 & 4.59 \\
\hline Distance to the sea & 70.73 & 19.19 & 82.35 & 70.79 & 24.25 & 92.98 & 71.78 & 67.22 & 25.48 \\
\hline Topoform altitude & 14.89 & 5.62 & 15.00 & 11.00 & 1.41 & 6.67 & 1.53 & 8.38 & 1.92 \\
\hline Vegetation coverage & 10.00 & 5.59 & 10.00 & 27.50 & 21.71 & 56.67 & 5.77 & 47.50 & 10.35 \\
\hline Number of plant species & 3.22 & 1.39 & 2.00 & 3.25 & 1.28 & 3.67 & 2.08 & 4.50 & 1.41 \\
\hline
\end{tabular}




\section{Table 6(on next page)}

Summary of canonical correspondence analysis for the first two axes at the embryo dunes of the Pacific Coast in Jalisco, México.

All bold values are significant at the level, $p<0.05$. 


\begin{tabular}{|c|c|c|}
\hline & Axis 1 & Axis 2 \\
\hline Eigenvalue & 0.427 & 0.212 \\
\hline Cumulative percentage variance of species-environment relation & 36.08 & 54.01 \\
\hline p-value Monte Carlo Test & 0.026 & 0.026 \\
\hline \multicolumn{3}{|l|}{ Correlations with individual environmental attributes } \\
\hline Latitudinal gradient & 0.084 & 0.061 \\
\hline Organic matter & -0.139 & -0.371 \\
\hline $\mathrm{pH}$ & 0.011 & -0.026 \\
\hline Electrical conductivity & 0.708 & 0.236 \\
\hline Very coarse sand & -0.126 & 0.391 \\
\hline Fine sand & 0.106 & 0.103 \\
\hline Magnetite & -0.106 & -0.195 \\
\hline Altitude of the topoform & 0.045 & -0.198 \\
\hline Vegetation coverage & -0.064 & 0.118 \\
\hline Distance to the sea & 0.272 & 0.079 \\
\hline Moisture retention & 0.262 & -0.002 \\
\hline Orientation of the topoform & -0.088 & 0.456 \\
\hline
\end{tabular}




\section{Table 7 (on next page)}

Correlation coefficients between plant species and some environmental variables.

r: Spearman's rho correlation coefficient, $p$ : $p$-value. 


\begin{tabular}{|c|c|c|c|c|c|c|}
\hline & & $\begin{array}{l}\text { Latitudinal } \\
\text { gradient }\end{array}$ & $\begin{array}{c}\text { Electrical } \\
\text { conductivity }\end{array}$ & $\begin{array}{l}\text { Very coarse } \\
\text { sand }\end{array}$ & $\begin{array}{l}\text { Distance to } \\
\text { the sea }\end{array}$ & $\begin{array}{l}\text { Orientation of } \\
\text { the topoform }\end{array}$ \\
\hline \multirow{2}{*}{ Prosopis juliflora } & $\mathrm{r}$ & 0.000 & 0.122 & 0.219 & -0.224 & 0.106 \\
\hline & $\mathrm{p}$ & 1.000 & 0.528 & 0.254 & 0.243 & 0.586 \\
\hline \multirow{2}{*}{ Canavalia rosea } & $\mathrm{r}$ & 0.143 & 0.227 & -0.281 & 0.287 & 0.276 \\
\hline & $\mathrm{p}$ & 0.458 & 0.236 & 0.139 & 0.131 & 0.148 \\
\hline \multirow{2}{*}{ Abronia maritima } & $\mathrm{r}$ & -0.122 & 0.230 & -0.163 & 0.189 & -0.320 \\
\hline & $\mathrm{p}$ & 0.529 & 0.230 & 0.399 & 0.325 & 0.091 \\
\hline \multirow{2}{*}{ Acalypha monostachya } & $\mathrm{r}$ & 0.227 & -0.490 & -0.042 & -0.227 & 0.110 \\
\hline & $\mathrm{p}$ & 0.236 & 0.007 & 0.829 & 0.236 & 0.569 \\
\hline \multirow{2}{*}{ Ipomoea pes-capreae } & $\mathrm{r}$ & 0.260 & -0.048 & -0.227 & 0.202 & 0.383 \\
\hline & $\mathrm{p}$ & 0.173 & 0.804 & 0.237 & 0.293 & 0.040 \\
\hline \multirow{2}{*}{ Okenia hypogaea } & $\mathrm{r}$ & 0.383 & -0.143 & 0.232 & -0.401 & -0.262 \\
\hline & $\mathrm{p}$ & 0.040 & 0.461 & 0.226 & 0.031 & 0.170 \\
\hline \multirow{2}{*}{ Pectis arenaria } & $\mathrm{r}$ & -0.034 & -0.093 & -0.094 & -0.034 & 0.304 \\
\hline & $\mathrm{p}$ & 0.861 & 0.630 & 0.629 & 0.861 & 0.109 \\
\hline \multirow{2}{*}{ Scaevola plumieri } & $\mathrm{r}$ & -0.096 & -0.060 & -0.168 & 0.143 & 0.138 \\
\hline & $\mathrm{p}$ & 0.622 & 0.758 & 0.385 & 0.458 & 0.476 \\
\hline \multirow{2}{*}{ Distichlis spicata } & $\mathrm{r}$ & 0.148 & -0.323 & -0.319 & -0.138 & 0.319 \\
\hline & $\mathrm{p}$ & 0.445 & 0.088 & 0.092 & 0.474 & 0.092 \\
\hline \multirow{2}{*}{ Jouvea pilosa } & $\mathrm{r}$ & 0.034 & -0.365 & 0.179 & 0.068 & -0.088 \\
\hline & $\mathrm{p}$ & 0.861 & 0.050 & 0.354 & 0.726 & 0.649 \\
\hline \multirow{2}{*}{ Uniola pittieri } & $\mathrm{r}$ & 0.027 & 0.514 & -0.407 & 0.271 & -0.101 \\
\hline & $\mathrm{p}$ & 0.889 & 0.004 & 0.029 & 0.156 & 0.601 \\
\hline
\end{tabular}




\section{Table 8(on next page)}

Plant species that determined the conformation of the groups in cluster analysis.

n: number of observations (sites) 


\begin{tabular}{ccccc}
\hline Group & n & Species & Sites with presence & Sites \% \\
\hline 1 & 9 & Abronia maritima & 1 & 11.1 \\
& & Uniola pittieri & 2 & 22.2 \\
\hline 2 & 7 & Abronia maritima & 1 & 14.3 \\
& Okenia hypogaea & 2 & 28.6 \\
& & Pectis arenaria & 7 & 100.0 \\
\hline 3 & Canavalia rosea & 1 & 14.3 \\
& & Okenia hypogaea & 7 & 100.0 \\
& & Scaevola plumieri & 1 & 14.3 \\
\hline 4 & Abronia maritima & 1 & 33.3 \\
& & Pectis arenaria & 2 & 66.7 \\
& 3 & Scaevola plumieri & 3 & 100.0 \\
\hline 5 & & Canavalia rosea & 3 & 100.0 \\
& & Pectis arenaria & 2 & 66.7 \\
& & Uniola pittieri & 1 & 33.3 \\
\hline
\end{tabular}

1 
Figure 1

Location of sample sites.

Map data @ 2021 Esri, Garmin, GEBCO, NOAA NGDC, INEGI. 


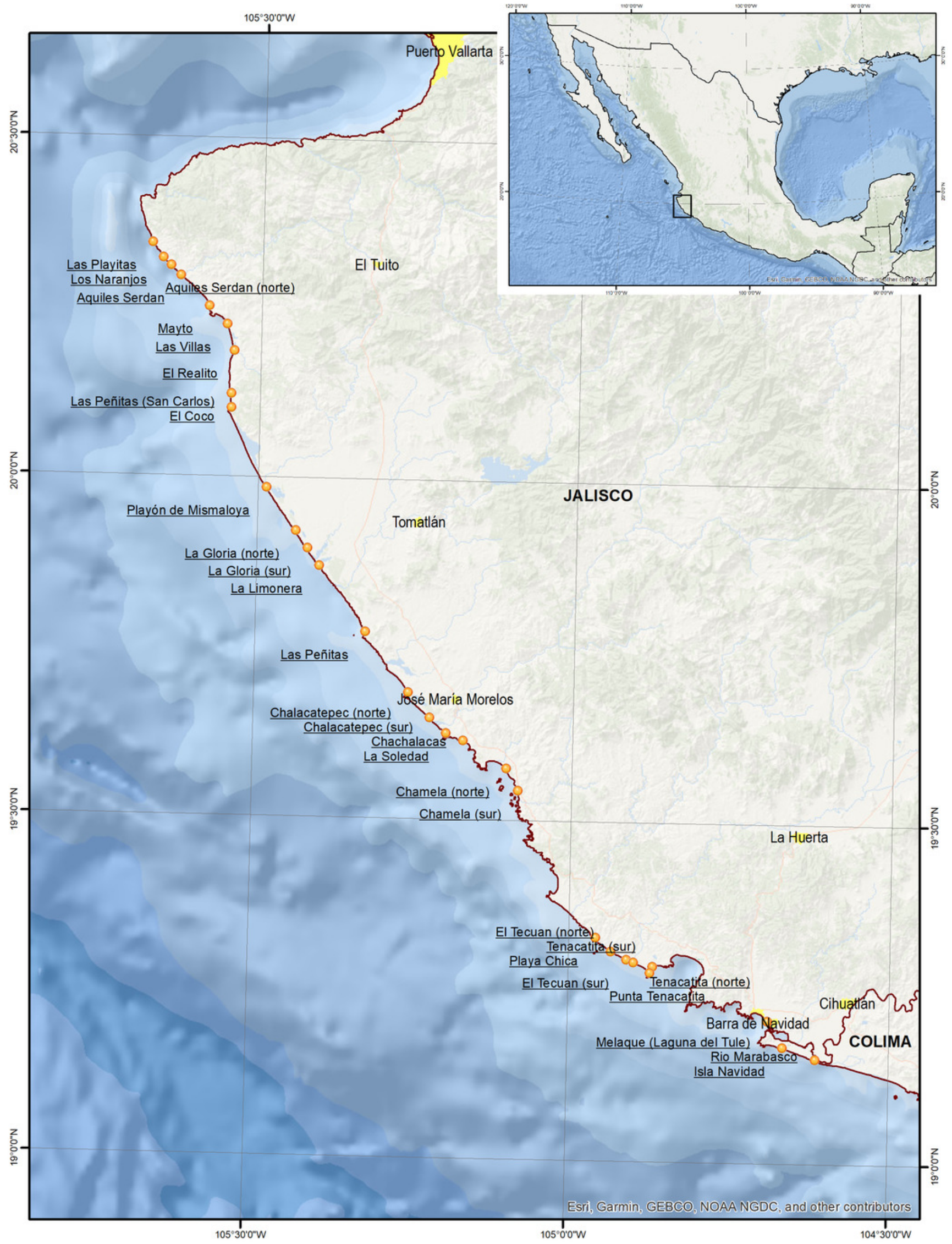


Figure 2

Exclusive plant species of embryo dunes in the study area.

a) Abronia maritima, b) Canavalia rosea, c) Okenia hypogaea, d) Pectis arenaria, e) Scaevola plumieri, f) Uniola pittieri. Photo Credit: Miguel Ángel Macías-Rodríguez. 


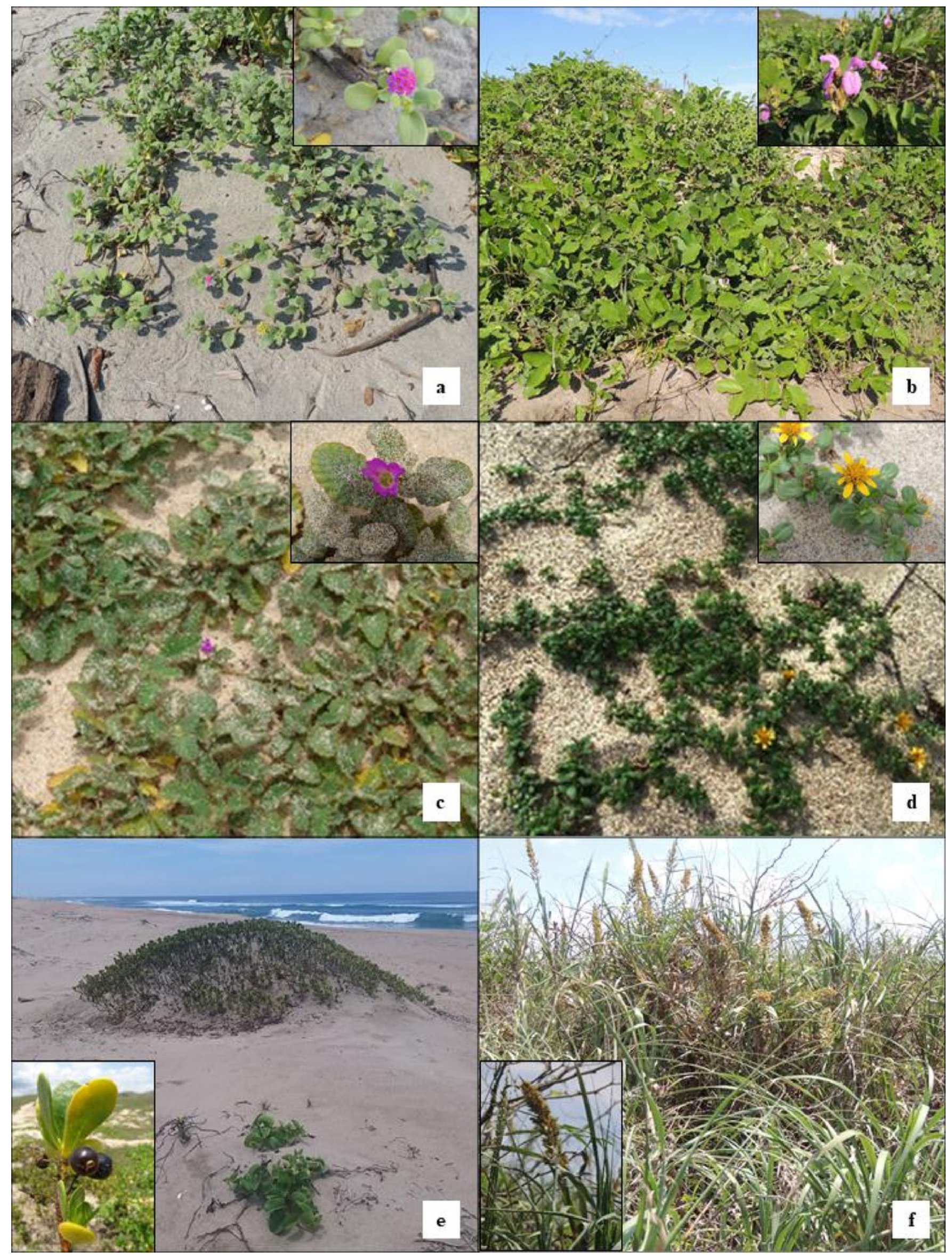


Figure 3

Scatter plot constructed with the PCA component scores.

The numbers framed within the plot correspond to the site number. 


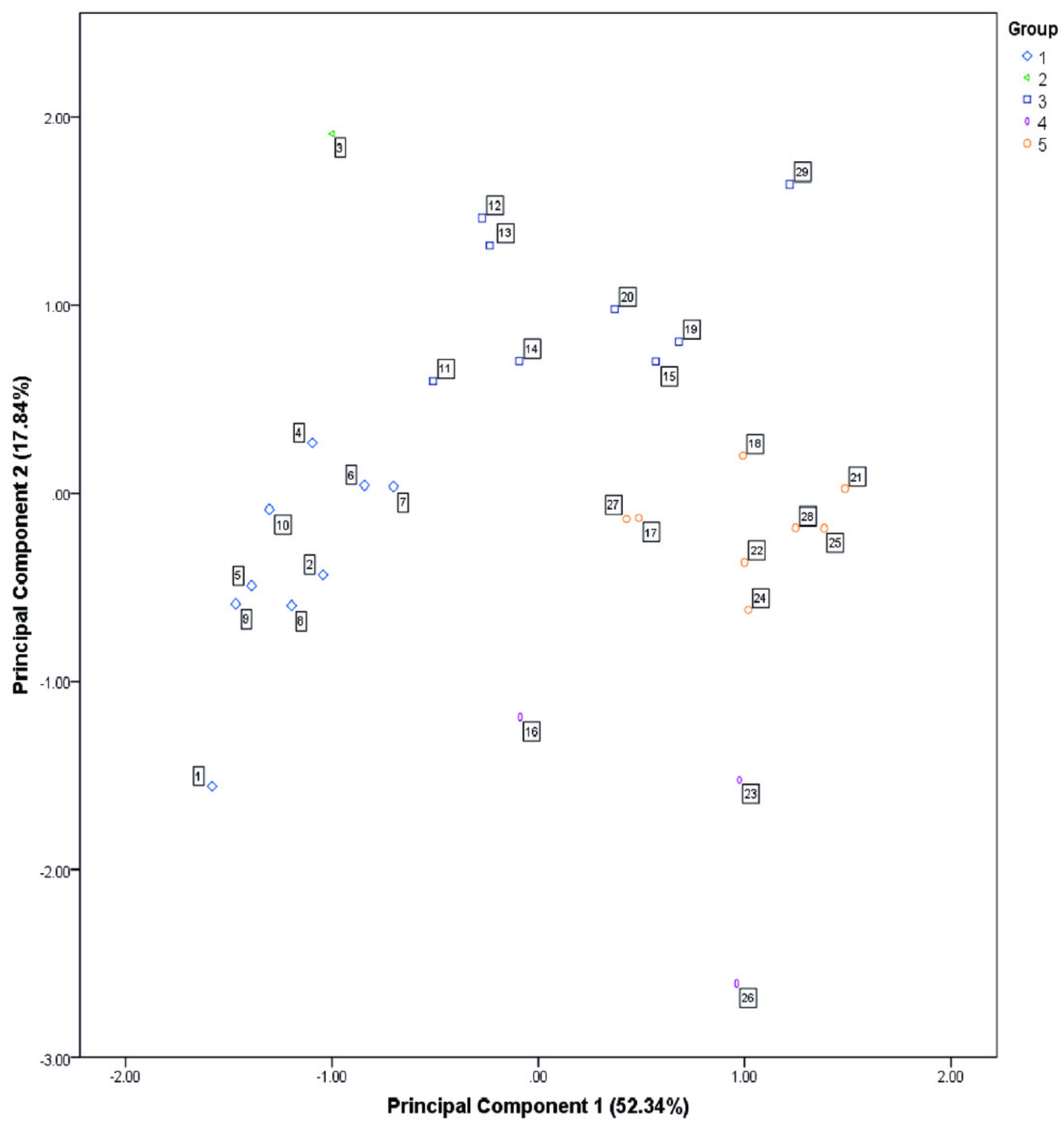




\section{Figure 4}

Ordination diagram that illustrates the relationships between environmental properties (lines) and plant species (dots).

Species: Abr: Abronia maritima, Aca: Acalypha monostachya, Can: Canavalia rosea, Dis:

Distichlis spicata, Ipo: Ipomoea pes-capreae, Jou: Jouvea pilosa, Oke: Okenia hypogaea, Pec:

Pectis arenaria, Pro: Prosopis juliflora, Sca: Scaevola plumieri, Uni: Uniola pittieri.

Environment variables: alt: Altitude of the topoform, cob: Vegetation coverage, dis: Distance

to the sea, lat: Latitudinal gradient, ori: Orientation of the topoform, af: Fine sand, amg: Very coarse sand, ce: Electrical conductivity, hum: Moisture retention, mg: Magnetite, mo: Organic matter, ph: pH. 


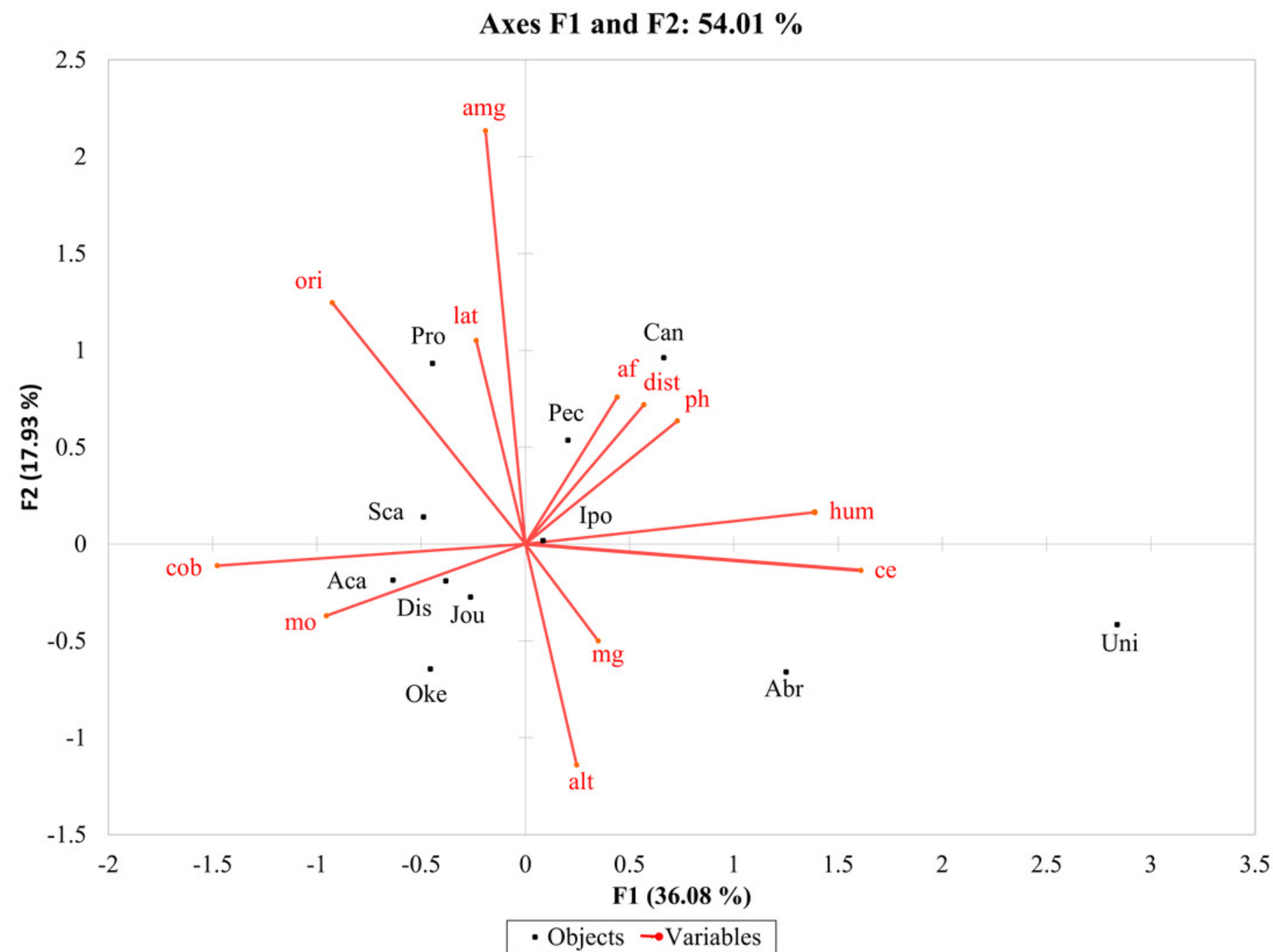


Figure 5

Geographic distribution of groups of sites according to environmental variables (GVA).

Map data (c) 2021 Esri, Garmin, GEBCO, NOAA NGDC, INEGI. 


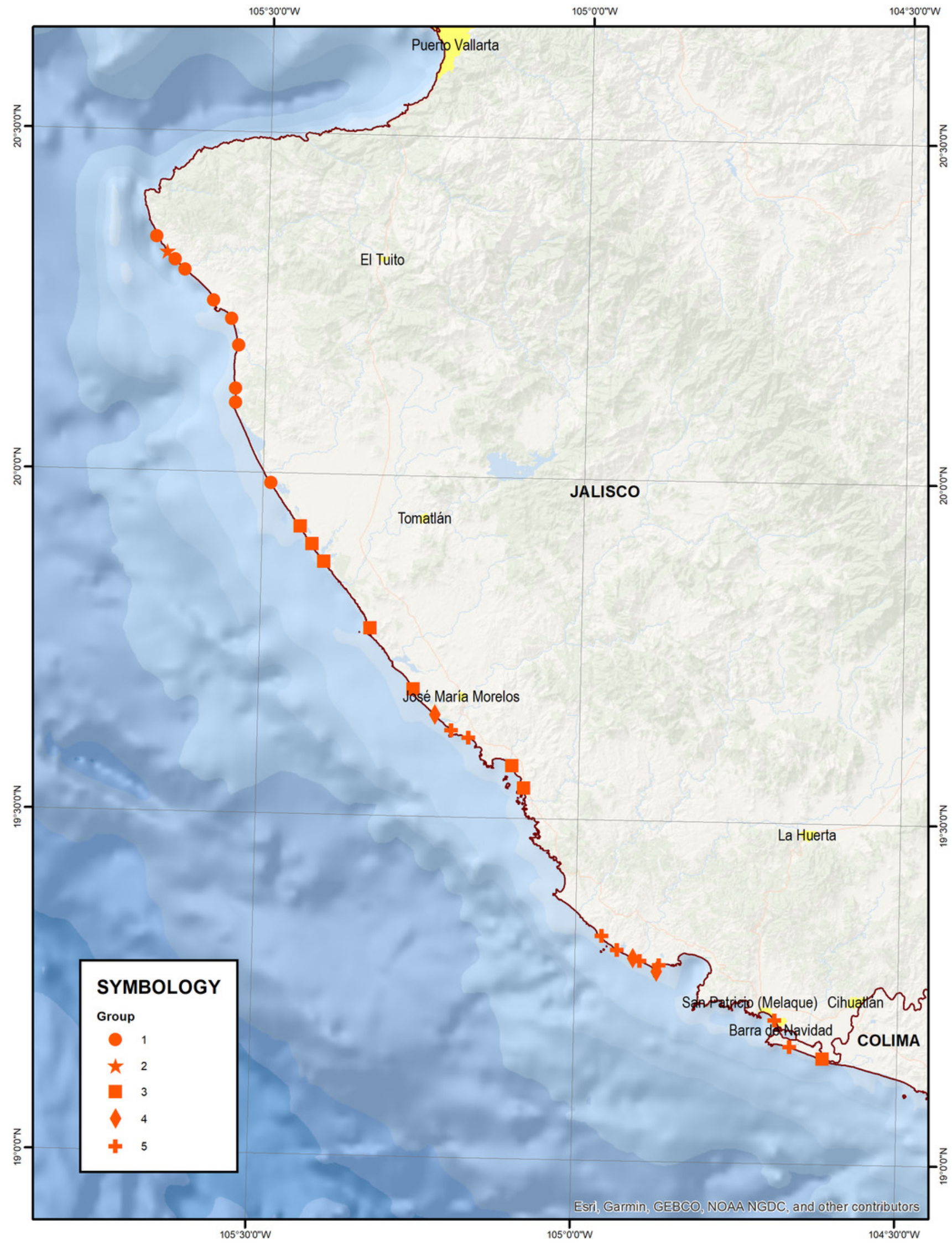


Figure 6

Geographic distribution of groups of sites according to the presence of plant species (GEF).

Map data @ 2021 Esri, Garmin, GEBCO, NOAA NGDC, INEGI. 


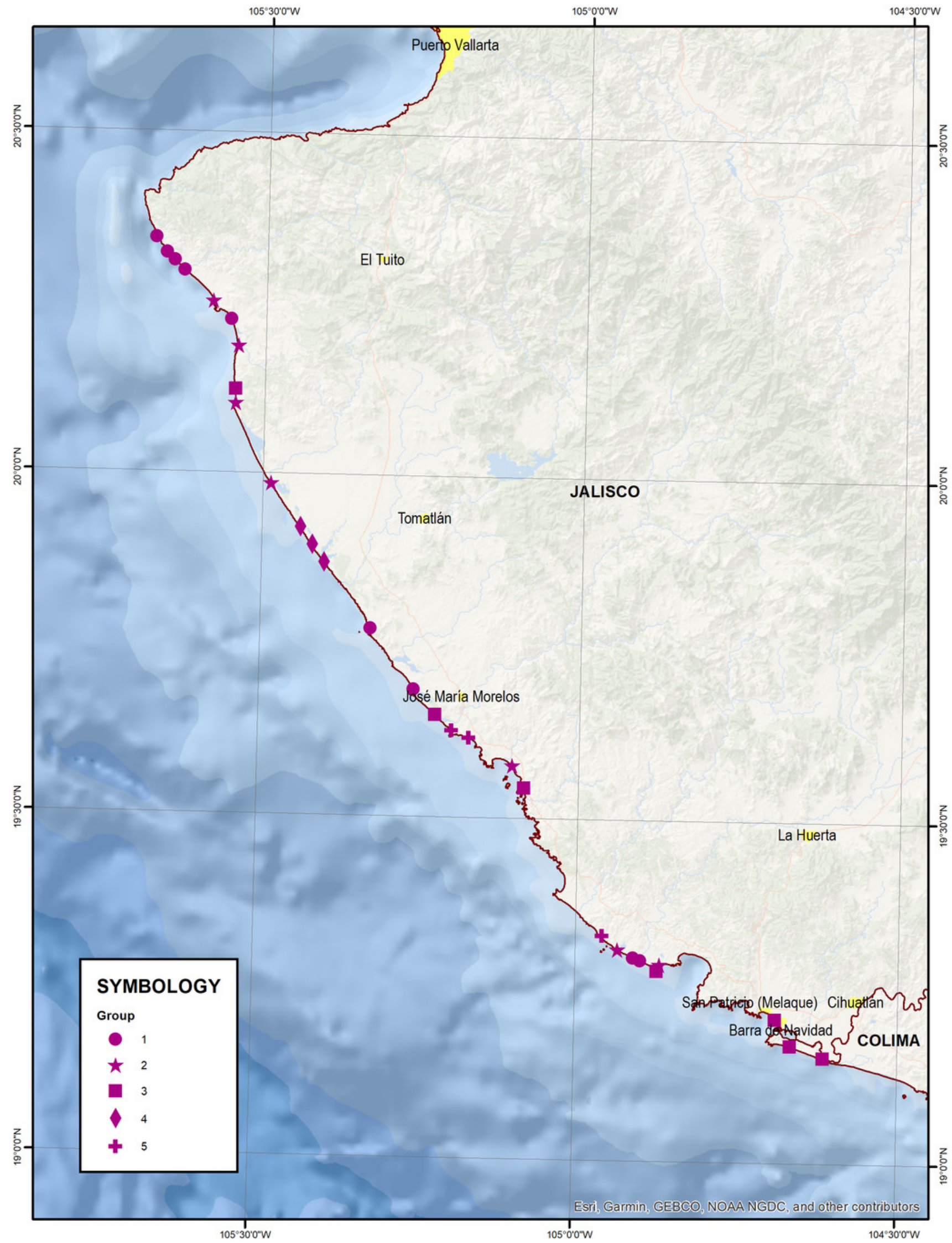

